\title{
A GREAT BIG MELTING POT: EXPLORING PATTERNS OF GLASS SUPPLY, CONSUMPTION AND RECYCLING IN ROMAN COPPERGATE, YORK*
}

\author{
C. M. JACKSON† \\ Department of Archaeology, University of Sheffield, Northgate House, West Street, Sheffield S1 4ET, UK \\ and S. PAYNTER \\ English Heritage, Fort Cumberland, Fort Cumberland Road, Eastney, Portsmouth PO4 9LD, UK
}

\begin{abstract}
One hundred and ninety three glass fragments from the canabae in York were analysed (first to fourth centuries). They fall into six compositional groups: antimony colourless (Sb), highmanganese (high-Mn), low-manganese (low-Mn), mixed antimony and manganese ( $S b-M n$ ), high iron, manganese and titanium (HIMT) and plant ash. Some groups represent production groups, some of which appear to be in limited supply in this western outpost, but are more prevalent elsewhere, and others reflect changing supply mechanisms. The majority of glasses fall into groups that demonstrate extensive recycling of glass. This has important implications for determining provenance using trace elements and isotopes.
\end{abstract}

KEYWORDS: ROMAN GLASS, NATURALLY COLOURED, COLOURLESS, ANTIMONY,
MANGANESE, PRODUCTION GROUPS, RECYCLING, BRITAIN, ICP-AES

\section{THE ROMAN GLASS FROM COPPERGATE}

Although perhaps best known for its Viking deposits (Hall 1984), the site at 16-22 Coppergate, York also produced deposits rich in Roman finds, including glass. The putative glass-making or glassworking remains have already been published (Jackson et al. 2003), but the site also yielded a large assemblage of glass fragments, typical of a consumption assemblage from the first to fourth centuries and which is probably unrelated to the glassworking debris found at the site (Jackson 1992). The assemblage comprises forms that can be dated from the first to fourth centuries and represents a microcosm of glass found in the western provinces at this period. The scale of the assemblage is not surprising: Eboracum (Roman York) was an important Roman centre in Britain, occupied from AD 71 to 410, housing a fortress and large manufacturing and civilian districts. Coppergate was outside the fortress, within the city walls, and is likely to have been a trading or manufacturing area as part of the canabae, although Roman remains from the site have been largely robbed (Mainman 1990).

Within scientific research into Roman glass, the composition of colourless glass has been well studied, as has later glass from the mid-third and fourth centuries onwards (e.g., Freestone et al. 2005; Jackson 2005; Paynter 2006; Silvestri et al. 2008; Foster and Jackson 2009, 2010; Gallo et al. 2013), but naturally coloured glass of the first to third centuries has often been neglected. 'Naturally coloured' here describes transparent glass with a range of mostly

\footnotetext{
*Received 17 June 2014; accepted 22 October 2014

$\dagger$ Corresponding author: email C.M.Jackson@Sheffield.ac.uk

(C) 2015 The Authors.

Archaeometry published by John Wiley \& Sons Ltd on behalf of University of Oxford

This is an open access article under the terms of the Creative Commons Attribution License, which permits use, distribution and reproduction in any medium, provided the original work is properly cited.
} 
blue-green hues caused by small amounts of iron oxide in the glass (Price and Cottam 1998), as opposed to containing intentionally added colourants. The Coppergate assemblage is significant because it includes naturally coloured, as well as colourless, glass in many common forms from a long-lived site, including many fragments that date from the second and third centuries. This study is therefore able to analyse a large corpus of material from a single site to demonstrate the availability of different raw glass types, and the extent of recycled glass within the trading network operating throughout the Roman world. By identifying changing glass compositions through time and noting which compositional types were used to manufacture different objects, the study will begin to fill a void in our knowledge of the consumption of glasses in the far north-west provinces. Within a system where glass was centrally produced and then distributed and reworked elsewhere, glass groups found in a British context can be compared to those found elsewhere across the empire (e.g., Arletti et al. 2008; Schibille et al. 2012; Gallo et al. 2013) to enable a better understanding of the complex web of the movement of raw glasses, the consumption of raw and recycled glass at different glass workshops, through to the use of different glass types in finished objects at settlement sites over a period of 400 years.

The samples chosen for analysis are representative of the glass artefacts found at the site. The use of diagnostic pieces from recognizable objects of known date allows a relative chronology to be determined for the different compositional groups of glass (Price and Cottam 1998), resulting in a broad timeline for each composition and form of the glass artefacts in circulation (especially important because of the disturbance of contexts at this site). The number of diagnostic forms included was limited because the analytical technique required relatively large samples and destructive sampling; therefore the use of non-diagnostic fragments provides further evidence for different compositions at the site. A variety of forms, typical of a large consumption assemblage, are represented, including vessels, such as bottles, cups, jars and beakers, and window glass, some produced by blowing and some by casting. The range of vessels shows that occupation at the site spanned the first to fourth centuries. These include first-century forms (Isings 3, pillar moulded bowls), globular jugs (first to early second centuries, Isings 52), cylindrical cups (second to third centuries, Isings 85b), cylindrical bottles (late second to early third centuries, Isings 50/51) and fourth-century conical beakers (Isings 106). This group of glasses is one of the largest assemblages of common types and forms from the late first to fourth centuries - but most importantly from the second and third centuries - to be analysed from Britain and as such provides a valuable data set of chemical compositions for naturally coloured and colourless glass in this period.

\section{THE PRODUCTION AND CIRCULATION OF ROMAN GLASS}

Roman glass was typically made with sand and natron (or trona) as the alkali, and it is now generally believed, as postulated by Sayre (1964) and Velde (1990), that the consistent composition seen in most Roman glass is because it was manufactured in large installations and then traded as raw glass. It was subsequently shaped into utilitarian objects at the many glassworking installations throughout the provinces. This hypothesis has since been strengthened by findings of large glass blocks, which appear to be the remains of broken raw glass slabs in various locations around the Roman world (Price 2005), and by the analysis of glass to determine trace element and isotopic compositions, which has placed these installations, for late Roman and Byzantine glass in particular, in the Eastern Mediterranean, in Syro-Palestine and in Egypt (Freestone et al. 2002; Foy et al. 2003; Brems and Degryse 2014). Thus a combination of 
archaeological investigation and chemical analysis has now allowed a small number of manufacturing groups with tentatively assigned provenances to be established, especially for the fourth century.

This paper uses the glass compositions from Coppergate, York, UK to establish which groups of glass were present in the north-west provinces from the first to fourth centuries and how different glass compositions were used. Only naturally coloured glass, which has a blue-green hue, and colourless glass are presented here, as these have not been modified with colourants or opacifiers and so form the best data set for examining the different manufacturing groups in circulation. The chemical groups determined in the analysis of the Coppergate glass will be discussed in the context of known glass types and also new groups or subgroups determined where the glass does not fit clearly into a defined group. The reasons for the development of new groups will be discussed in the context of our understanding of glass manufacture in the Roman period.

\section{METHODS}

The glass samples were solubilized using the method devised for silicates and analysed by ICP-AES at the Geology Department, Royal Holloway University of London. The materials, methods, instrumentation and data validation are given in Jackson et al. (2003). Although the sample dissolution method loses silica by volatilization, it has the advantage of providing a large, accurate data set, including elements at major, minor and trace concentrations. Eleven elements are given as oxides in wt\% and 10 as ppm. Lead and antimony concentrations were calculated separately using prepared single element standards and Corning and NIST glass standards of known composition. A subsection of the data has been presented previously (Jackson 2005) in the context of colourless glass; these data are discussed here as part of the Coppergate assemblage as a whole and in the light of the production groups that have been identified more recently, or defined here.

\section{RESULTS: IDENTIFICATION OF COMPOSITIONAL GROUPS}

The results of 193 analyses of naturally coloured and colourless glass dating from the first to fourth centuries are presented in Appendix 1. The glass can be defined by six compositional groups: (1) antimony colourless (Sb); (2) low-manganese (low-Mn); (3) high-manganese (high$\mathrm{Mn}$ ); (4) high iron, manganese and titanium (HIMT) (including weak and strong variants); (5) plant ash; and (6) mixed antimony-manganese ( $\mathrm{Sb}-\mathrm{Mn}$ ) (with the possible inclusion of a seventh group of 'Levantine 1'; see below). The mean compositions of the groups can be seen in Table 1 . In addition, there are eight outliers that do not clearly fit into any of these groups.

Although other compositional differences relating to the primary glass-forming components used in manufacture will be discussed, the groups can broadly be described by their concentrations of antimony and manganese (Fig. 1 (a)). Comparative data from previously published analyses to support the definitions of these groups are presented in Appendix 2.

\section{Antimony colourless ( $\mathrm{Sb}$ )}

This group of colourless glasses is well represented in assemblages from the first to third centuries. It is a very coherent group, manufactured with high-purity sands, containing low concentrations of alumina, titanium, calcium and often iron, and is also soda rich (Jackson 2005 
Table 1 Means and ranges of the compositional groups identified in the glass analysed from Coppergate, York (note that ranges are affected by sample size and relate to this data set only). Key as in Appendix 1

\begin{tabular}{|c|c|c|c|c|c|c|c|}
\hline No. & $\begin{array}{l}S b \\
44\end{array}$ & $\begin{array}{c}S b-M n \\
80\end{array}$ & $\begin{array}{c}\text { High-Mn } \\
13\end{array}$ & $\begin{array}{c}\text { Low-Mn } \\
26\end{array}$ & $\begin{array}{c}H I M T 2(W) \\
19\end{array}$ & $\begin{array}{c}\operatorname{HIMT1}(S) \\
1\end{array}$ & $\begin{array}{l}\text { Plant ash } \\
2\end{array}$ \\
\hline \multicolumn{8}{|l|}{$W t \%$} \\
\hline \multirow[t]{2}{*}{$\mathrm{Al}_{2} \mathrm{O}_{3}$} & 1.97 & 2.40 & 2.92 & 2.67 & 2.38 & 2.62 & 2.28 \\
\hline & $1.62-2.49$ & $1.78-2.83$ & $2.65-3.28$ & $2.28-3.04$ & $2.08-4.11$ & & $2.25-2.31$ \\
\hline \multirow{2}{*}{$\mathrm{Fe}_{2} \mathrm{O}_{3}$} & 0.37 & 0.58 & 0.46 & 0.31 & 0.63 & 1.17 & 0.75 \\
\hline & $0.22-0.80$ & $0.27-0.98$ & $0.30-0.64$ & $0.24-0.40$ & $0.32-0.83$ & & $0.70-0.79$ \\
\hline \multirow[t]{2}{*}{$\mathrm{MgO}$} & 0.48 & 0.58 & 0.63 & 0.50 & 0.71 & 1.27 & 1.35 \\
\hline & $0.3-0.87$ & $0.39-0.86$ & $0.51-0.88$ & $0.43-0.65$ & $0.42-0.88$ & & $1.29-1.41$ \\
\hline \multirow{2}{*}{$\mathrm{CaO}$} & 5.82 & 6.59 & 8.48 & 7.66 & 6.19 & 6.48 & 8.07 \\
\hline & $4.49-7.54$ & $5.19-8.15$ & $7.86-9.04$ & $7.02-8.24$ & $4.86-7.66$ & & $7.25-8.89$ \\
\hline \multirow{2}{*}{$\mathrm{Na}_{2} \mathrm{O}$} & 19.39 & 18.69 & 16.81 & 17.47 & 19.41 & 19.26 & 17.82 \\
\hline & 17.99-20.62 & $16.20-20.42$ & $14.76-18.39$ & $16.03-19.87$ & $17.20-20.46$ & & $16.92-18.71$ \\
\hline \multirow[t]{2}{*}{$\mathrm{K}_{2} \mathrm{O}$} & 0.51 & 0.82 & 0.68 & 0.67 & 0.87 & 0.56 & 1.61 \\
\hline & $0.36-0.74$ & $0.47-1.56$ & $0.46-0.85$ & $0.46-1.71$ & $0.51-1.26$ & & $1.51-1.71$ \\
\hline \multirow[t]{2}{*}{$\mathrm{TiO}_{2}$} & 0.07 & 0.09 & 0.08 & 0.07 & 0.11 & 0.23 & 0.14 \\
\hline & $0.04-0.13$ & $0.05-0.14$ & $0.07-0.09$ & $0.06-0.08$ & $0.07-0.14$ & & $1.12-0.16$ \\
\hline \multirow[t]{2}{*}{$\mathrm{P}_{2} \mathrm{O}_{5}$} & 0.04 & 0.11 & 0.11 & 0.13 & 0.09 & 0.06 & 0.40 \\
\hline & $0.02-0.08$ & $0.04-0.19$ & $0.08-0.19$ & $0.10-0.15$ & $0.04-0.28$ & & $0.35-0.45$ \\
\hline \multirow[t]{2}{*}{$\mathrm{MnO}$} & 0.03 & 0.40 & 1.15 & 0.34 & 0.87 & 1.8 & 0.12 \\
\hline & $0.01-0.09$ & $0.10-1.01$ & $0.84-1.66$ & $0.02-0.79$ & $0.65-1.03$ & & $\sim$ \\
\hline \multirow[t]{2}{*}{$\mathrm{PbO}$} & 0.04 & 0.06 & 0.01 & $<0.01$ & 0.03 & 0.03 & 0.01 \\
\hline & b.d. -0.39 & b.d. -0.45 & b.d. -0.02 & b.d. -0.02 & b.d. -0.05 & & b.d. -0.01 \\
\hline \multirow[t]{2}{*}{$\mathrm{Sb}_{2} \mathrm{O}_{5}$} & 0.54 & 0.35 & 0.04 & $<0.01$ & 0.10 & 0.03 & 0.18 \\
\hline & $0.05-0.89$ & $0.11-0.69$ & $0.01-0.08$ & $0.01-0.01$ & $0.01-0.17$ & & $0.13-0.23$ \\
\hline \multicolumn{8}{|l|}{ ppm } \\
\hline \multirow[t]{2}{*}{$\mathrm{Ba}$} & 147 & 229 & 432 & 243 & 273 & 342 & 191 \\
\hline & $127-165$ & $149-341$ & $282-581$ & $203-310$ & $218-467$ & & 189-192 \\
\hline \multirow{2}{*}{$\mathrm{Cu}$} & 16 & 155 & 18 & 15 & 88 & 51 & 41 \\
\hline & $5-78$ & $14-1718$ & $9-27$ & 4-39 & $11-219$ & & $34-47$ \\
\hline \multirow[t]{2}{*}{$\mathrm{Li}$} & 10 & 17 & 10 & 8 & 18 & 16 & 9 \\
\hline & $5-18$ & $7-59$ & $7-14$ & $6-14$ & $8-32$ & & $8-9$ \\
\hline \multirow[t]{2}{*}{$\mathrm{Ni}$} & 12 & 16 & 19 & 15 & 19 & 29 & 13 \\
\hline & $8-19$ & $7-24$ & $13-24$ & $6-49$ & $13-22$ & & $12-14$ \\
\hline \multirow[t]{2}{*}{$\mathrm{Sr}$} & 414 & 415 & 506 & 430 & 445 & 588 & 642 \\
\hline & $286-579$ & $334-516$ & $450-569$ & $368-537$ & $348-675$ & & $580-703$ \\
\hline \multirow[t]{2}{*}{ V } & 9 & 17 & 25 & 15 & 22 & 35 & 15 \\
\hline & $5-16$ & $7-29$ & $13-62$ & $7-27$ & $19-28$ & & $13-16$ \\
\hline \multirow[t]{2}{*}{$\mathrm{Y}$} & 7 & 8 & 9 & 9 & 8 & 10 & 7 \\
\hline & $60-9$ & $6-10$ & $8-10$ & $8-10$ & $9-9$ & & $\sim$ \\
\hline \multirow[t]{2}{*}{$\mathrm{Zn}$} & 21 & 36 & 17 & 17 & 36 & 31 & 32 \\
\hline & $15-36$ & $21-108$ & $1-25$ & $11-28$ & $18-57$ & & $30-34$ \\
\hline \multirow[t]{2}{*}{$\mathrm{La}$} & 11 & 12 & 11 & 11 & 12 & 13 & 11 \\
\hline & $10-12$ & $10-14$ & $9-13$ & $10-12$ & $11-13$ & & $\sim$ \\
\hline \multirow[t]{2}{*}{$\mathrm{Ce}$} & 18 & 20 & 20 & 19 & 21 & 25 & 20 \\
\hline & $14-23$ & $13-26$ & $17-24$ & $16-24$ & $16-24$ & & $18-21$ \\
\hline
\end{tabular}


(a)

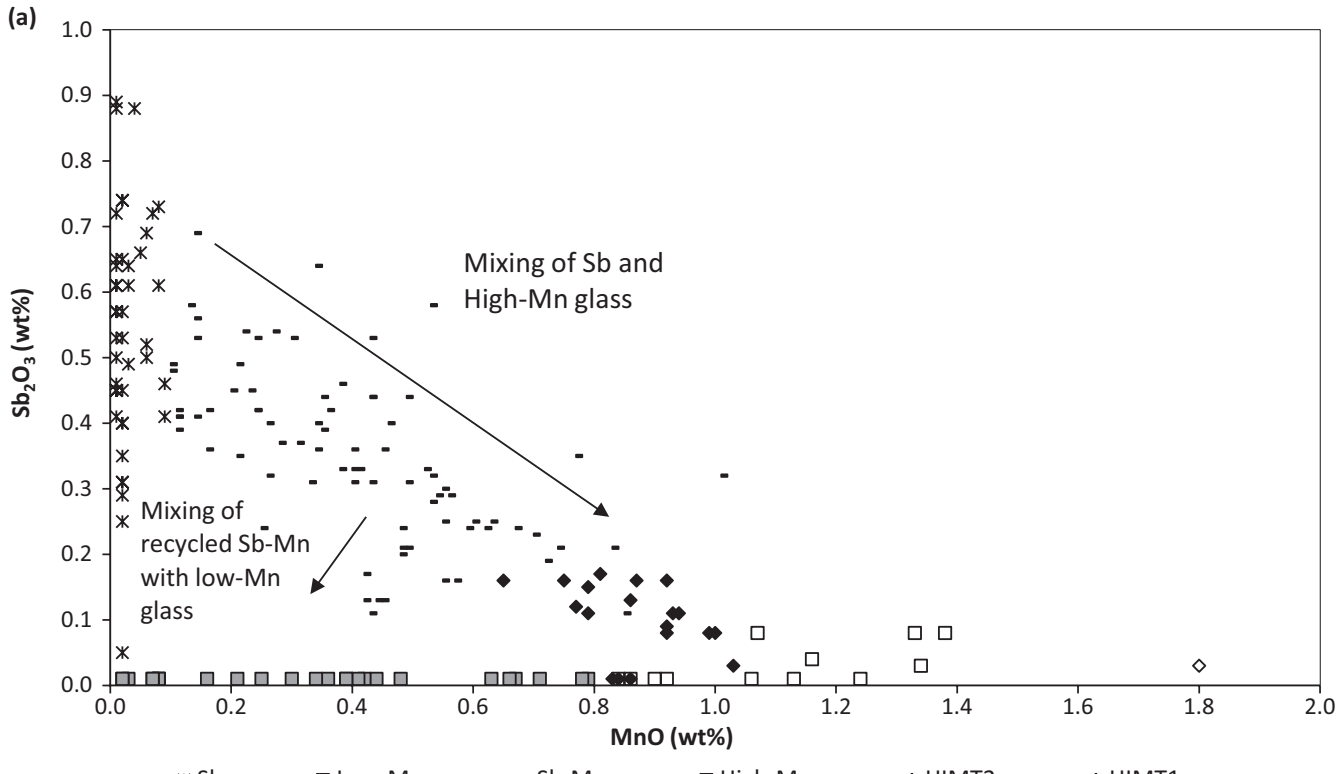

(b)

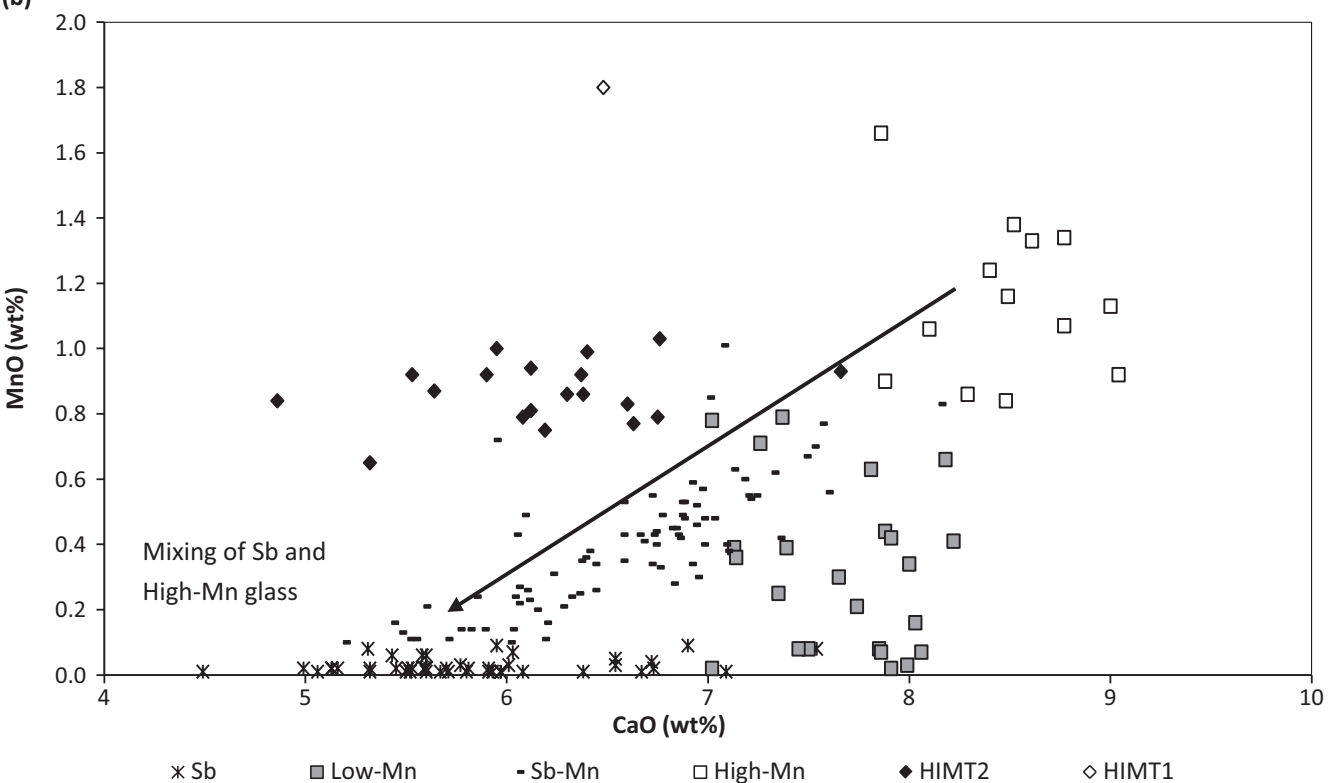

Figure 1 (a) A plot of manganese versus antimony oxides for the Roman glass from Coppergate, York, showing the spread of manganese and antimony oxide contents for the mixed glass, between the Sb and high-Mn glass compositions. (b) A plot of calcium versus manganese oxide for the Roman glass from Coppergate, York, showing how the lime and manganese contents are correlated in the Sb-Mn glass, best fitting a mixture of high-manganese (high-Mn) glass with antimony colourless $(\mathrm{Sb})$ glass. 
(groups 1a and 1b); Paynter 2006; and reviewed in Paynter and Jackson forthcoming) (Figs 2 (a) and 2 (b)); the decolourizer is antimony. Paynter (2006) suggests there is a variant of this composition, which is low in lime, alumina and barium and often contains very high levels of antimony ( $\mathrm{Sb} / \mathrm{low}-\mathrm{Ca}$ ); and is found amongst very early, high-quality vessels (Appendix 2). This variant is not present in the glasses analysed here (Fig. 2 (c)). Similarly, the presence of (>300 ppm) lead in some early colourless Roman glass (Baxter et al. 2005), suggested by Paynter (2010) to derive from a lead-bearing antimony source, is seen in only three examples, one of which is dated to the first century (Appendix 1). Current research suggests that the antimony colourless glass may originate in the Eastern Mediterranean (Ganio et al. 2012), although Italy has also been postulated as a possible origin for glass with these compositional characteristics (Brems and Degryse 2014). The absence of the Sb/low-Ca glass composition and the low numbers of lead-bearing antimony examples reflect the date of the Coppergate assemblage. Since most diagnostic fragments are from the second and third centuries, they postdate these earlier compositional traits, and few high-status vessels of the type typically made from the rarer $\mathrm{Sb} / \mathrm{low}-\mathrm{Ca}$ composition are represented.

\section{Low-manganese (low-Mn)}

This group of naturally coloured glasses, predominantly blue-green or 'aqua', generally contains low concentrations of manganese of up to $0.8 \mathrm{wt} \%$, but no antimony (Fig. 1). This glass tends to contain less soda, but more alumina, than the Sb colourless glass (Figs 2 (a) and 2 (b)). This naturally coloured glass is known from Roman assemblages elsewhere and is the dominant, raw, blue-green glass by the first century, and is thought to be manufactured in the Syria-Palestine region (Foy et al. 2000) (Appendix 2). The Coppergate samples also contain a subset of the 'light green' examples, which contain very little manganese oxide (less than $0.1 \mathrm{wt} \%$ ), but otherwise fit the general compositional patterning for low-Mn glasses.

\section{High-manganese (high-Mn)}

This composition is characterized by high concentrations of manganese $(0.8-1.5 \mathrm{wt} \%)$ but in other respects is similar to the low-Mn glass, but with slightly higher calcium and lower soda (Figs 1, 2 (b) and 2 (c)). The lower MnO threshold of $0.8 \mathrm{wt} \%$ was selected because it is the approximate minimum seen in manganese decolourized glass, such as the first-century colourless examples from Adria studied by Gallo et al. (2013) (Appendices 1 and 2). The higher MnO threshold of $1.5 \mathrm{wt} \%$ for this group was selected to exclude deliberately coloured purple glass. In many reported instances, the high-Mn composition produces a colourless glass, especially where the manganese concentrations are at the higher end of the range (see Vichy et al. 2003; Silvestri et al. 2008; Foster and Jackson 2010; Schibille et al. 2012; Gliozzo et al. 2013; Paynter and Jackson forthcoming); however, all the samples analysed here have a blue or light green hue (one nearly colourless) and cannot be distinguished visually from other blue-green or naturally coloured glasses (e.g., low-Mn).

The separation of Levantine 1, low-Mn and high-Mn is in terms of manganese content and date, since the base glass composition appears very similar otherwise (Foster and Jackson 2010); this might suggest they have a similar provenance or are a continuation of a manufacturing tradition (Appendix 2). Taking into account the similarities in composition, three late Roman samples from Coppergate (5495, 13535 and 14069), assigned here to the high-Mn group, may be the same as the Levantine 1a group of Foster and Jackson (2009). 
(a)

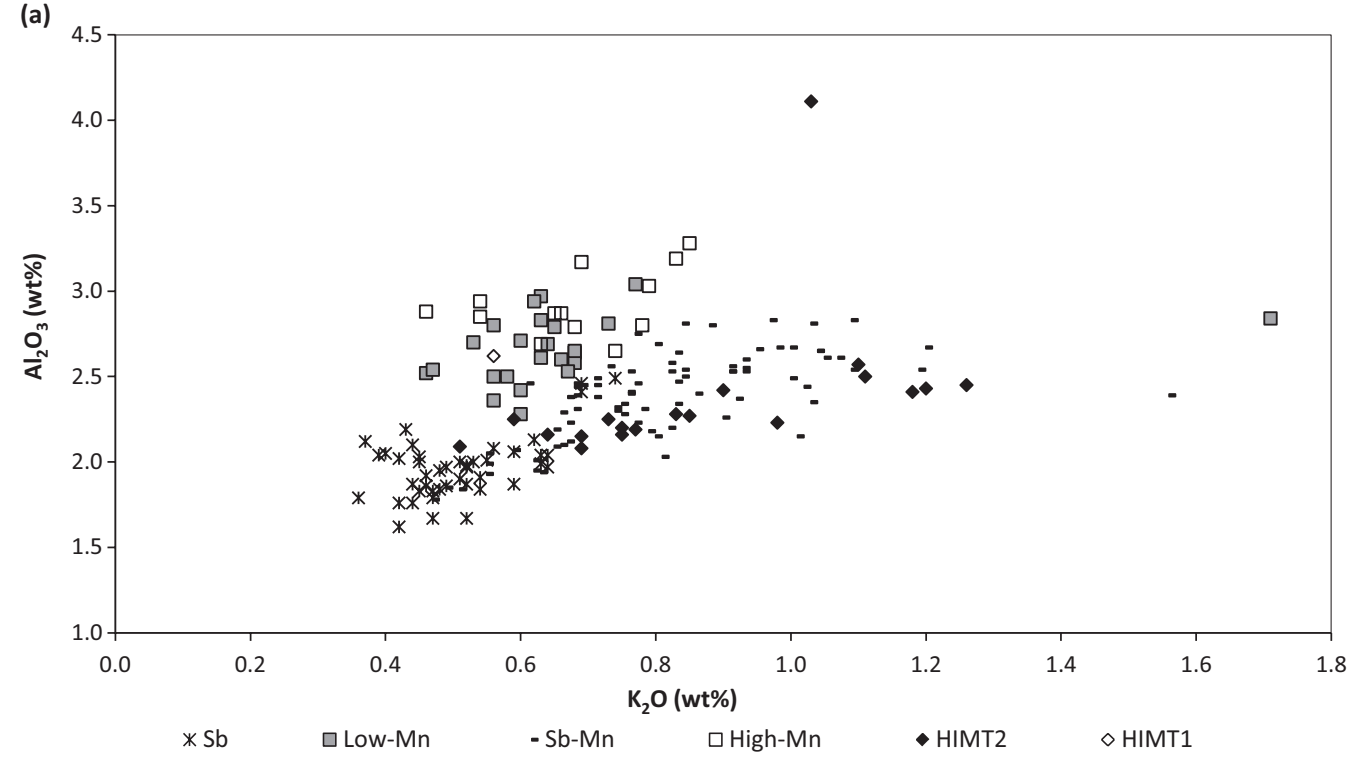

(b)

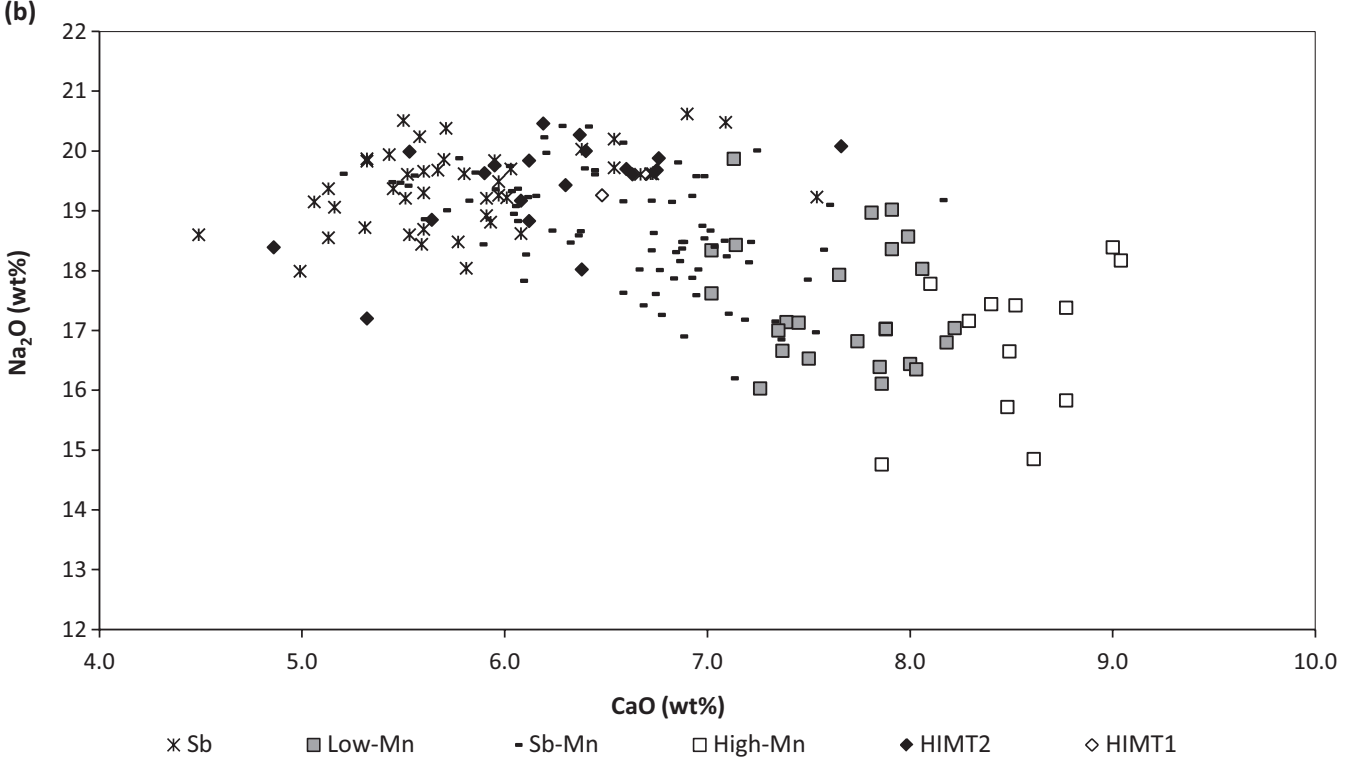

Figure 2 A plot of oxides for the Roman glass from Coppergate, York, showing the different glass groups represented: (a) $\mathrm{Al}_{2} \mathrm{O}_{3}$ versus $\mathrm{K}_{2} \mathrm{O}$; (b) $\mathrm{Na}_{2} \mathrm{O}$ versus $\mathrm{CaO}$; (c) Ba versus $\mathrm{MnO}$; (d) Cu versus PbO. In all charts, the Sb-Mn group shows significant mixing.

From the fourth century onwards, the compositional range of manganese-containing glass becomes even more diverse, as illustrated by Foster and Jackson (2010) and Meek (2013), who have identified two groups of colourless high-manganese glasses, differing in their soda and calcium concentrations. Meek's (2013) type 2b matches the high-Mn glasses here. Meek's 2a and 


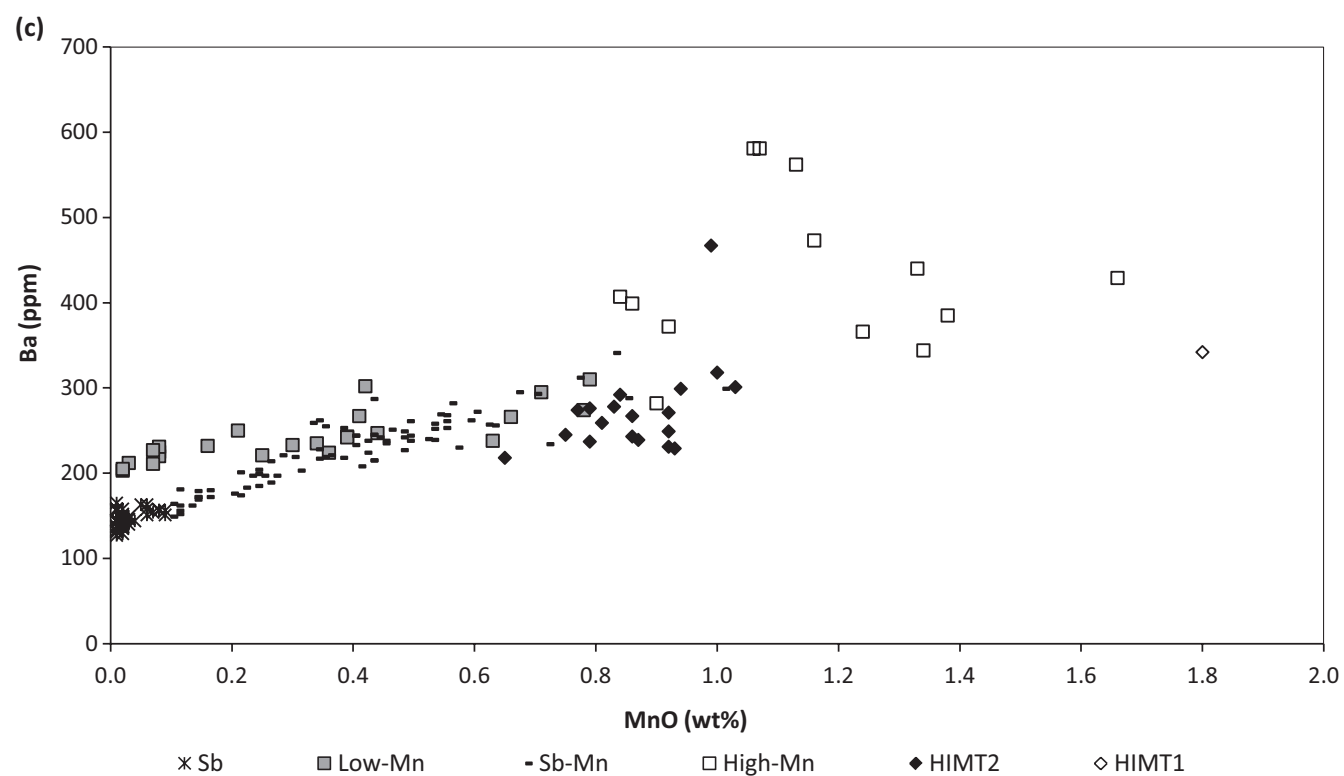

(d)

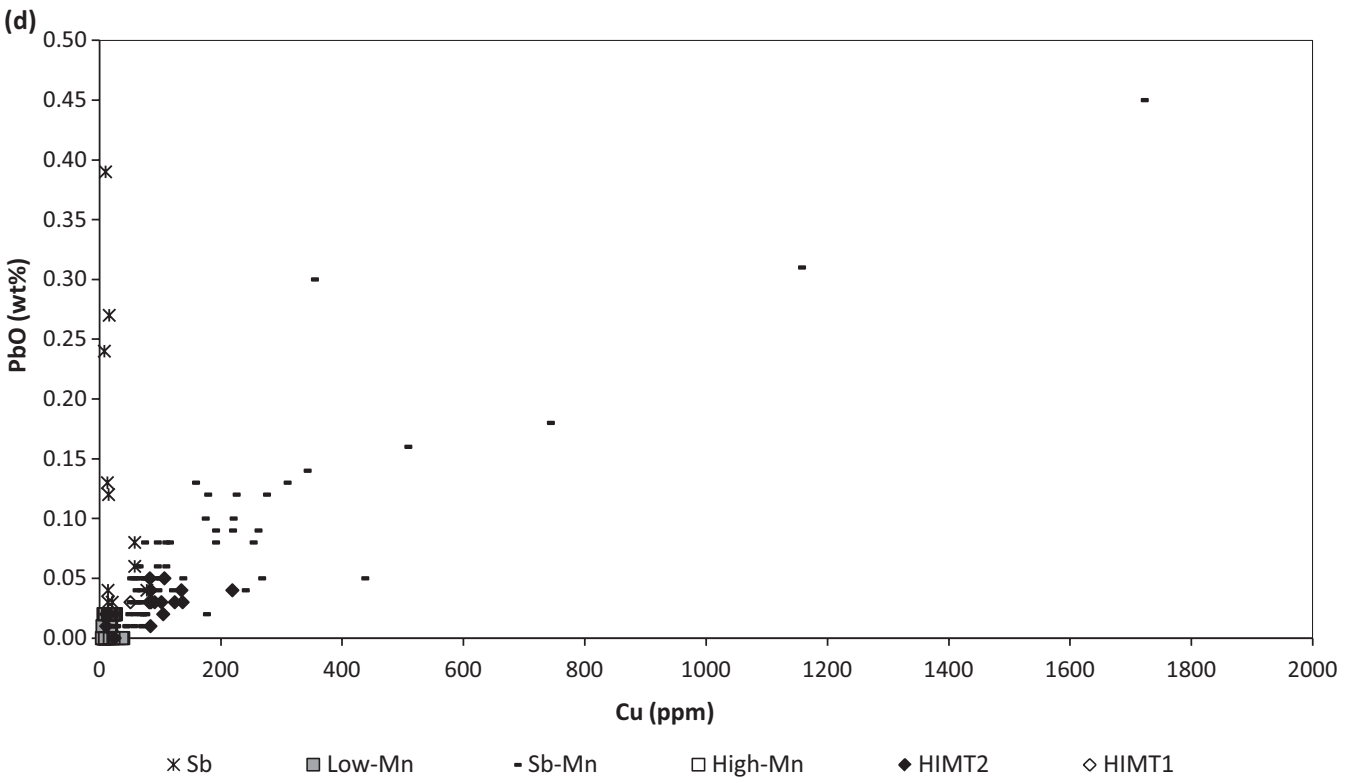

Figure 2 (Continued)

Foster and Jackson's (2010) 2a have higher concentrations of soda and less lime (Manganese low lime in Appendix 2); these glasses also have slightly elevated concentrations of magnesium, iron and titanium oxides and may resemble weak HIMT (below). The colourless $2 \mathrm{~b}$ in Foster and Jackson (2010) has high lime and high soda, which indicates the presence of another group not represented here, and further illustrates the varied nature of manganese-containing glass from the fourth century. 


\section{Mixed antimony and manganese ( $S b-M n)$}

This is the largest compositional group amongst the analysed glass. Sb-Mn glass contains both manganese and antimony, which were probably introduced by recycling the main antimony- or manganese-containing raw glass at the time (see Discussion). Slightly raised concentrations of other elements, such as copper and occasionally lead in the Sb-Mn glass and the large range of soda, calcium and alumina concentrations, nevertheless correlated, also suggest that this is a mixed recycled group rather than a primary production group (Figs 2 (a), 2 (b) and 2 (d)). As new types of raw glass are introduced and start to be recycled, such as HIMT in the third and fourth centuries, even greater variation is seen within the $\mathrm{Sb}-\mathrm{Mn}$ glass group.

$\mathrm{Sb}-\mathrm{Mn}$ glass has a range of hues depending on the relative proportions of antimony to manganese, and the concentration of iron oxide present. Published examples of Sb-Mn glasses containing a larger proportion of antimony (from antimony decolourized glass) are more likely to be colourless and so have previously been discussed in terms of colourless Roman glass assemblages (Mirti et al. 1993; Jackson 2005 (2b); Paynter 2006; Silvestri et al. 2008). However, those samples containing a smaller proportion of the antimony to manganese, or those that contain more iron oxide, are more likely to be naturally coloured blue, blue-green or green, and have been discussed along with naturally coloured glasses (e.g., Mirti et al. 1993; Jackson 1994; Silvestri 2008) (Appendix 2). Regardless of their colour, they are discussed as a single compositional group here.

\section{High iron, manganese and titanium glass (HIMT)}

As the name suggests, HIMT glass can be distinguished by elevated levels of iron, manganese and titanium relative to other glass types (Freestone 1994; Foy et al. 2003). These features, along with higher soda and lower lime concentrations, distinguish it from other manganese-bearing glass types such as high-Mn and low-Mn glass (Fig. 2 (b)). The glass assigned to this group displays a broad range of compositions, which Freestone (1994) ascribed to the mixing of two components during glass production (as opposed to mixing with other glass types during the recycling process). Evidence for further dilution of the HIMT composition through recycling has been identified in some examples from Western Europe, which show antimony, lead and copper contamination (Foy et al. 2003; Foster and Jackson 2009; Jackson and Price 2012). However, it is impossible to determine the extent of recycling in HIMT glasses, as recycling using glass of the same composition (e.g., HIMT with HIMT) would be undetectable.

HIMT, thought to originate in Egypt (Foy et al. 2003; Freestone et al. 2005), is increasingly common from about the mid-fourth century (Mirti et al. 1993; Freestone et al. 2005; Foster and Jackson 2009) (Appendix 2). Further chronological patterns have also been noted within the group: Foster and Jackson (2009) suggested that a weaker variant of HIMT (their HIMT 2) was introduced in Britain around AD 330, slightly preceding a stronger type (their HIMT 1). Foy et al. (2003) determined that a yet more concentrated variant (their group 1) was in use in the fifth century across a considerable area, before 'weakening' again in the sixth to eighth centuries (their group 2). The HIMT glass in the Coppergate assemblage is predominantly HIMT2, with one possible example of strong HIMT1 glass. The Coppergate weak HIMT examples also contain low levels of antimony oxide, which suggests that these may be a recycled combination of HIMT glass with an antimony-bearing glass, such as the $\mathrm{Sb}$ colourless or recycled $\mathrm{Sb}-\mathrm{Mn}$ types. The high concentrations of potash in some of the HIMT samples from Coppergate (above $1 \mathrm{wt} \%$, Fig. 2 (a)) may also suggest contamination through recycling (see Discussion). 


\section{Levantine 1 glass}

This term has been used to describe glass of the fourth century and later, which is high in lime and alumina and low in soda (Appendix 2) (Brill 1988; Freestone et al. 2000; Foster and Jackson 2009). In terms of bulk composition, Levantine 1 glass is similar to the earlier glass groups high-Mn and, to a lesser extent, low-Mn. However, it generally does not contain any decolourizer (Freestone et al. 2000; but see summary in Foster and Jackson 2009) and this also differentiates it from most other first- to fourth-century types. Analysis of glass from tank furnaces at Apollonia has demonstrated that this glass was manufactured on the Levantine coast (Foy et al. 2003; Tal et al. 2004). Although fourth-century glass is present at Coppergate, no samples of Levantine 1 composition were identified (but see the section on high-Mn glasses). This outcome is not unexpected, as Foster and Jackson (2009) note that this glass is poorly represented in late Roman assemblages in Britain.

\section{Plant-ash glass}

Two glass samples, one from a cast window and the other from a bottle, which have mixed concentrations of antimony and manganese, also contain elevated concentrations of potash, magnesia (both around $1.5 \mathrm{wt} \%$ ) and phosphorus (around $0.4 \mathrm{wt} \%$ ) (Appendix 1 and Table 1). This may indicate that these glasses were made wholly or in part using soda plant ashes, or from recycled glass including some made with high-soda plant ashes or were potentially contaminated with fuel ash (Paynter 2008). Roman glasses made from plant ashes have been noted in other contexts, including strongly coloured first-century glasses (e.g., Arletti et al. 2008; Jackson et al. 2009; Gallo et al. 2013; Jackson and Cottam in prep.). Plant-ash compositions tend to be rare in most Roman glass assemblages and have only been noted relatively recently; their provenance has been a matter of speculation.

\section{Outliers}

Eight samples do not fall clearly into any of the groups defined above (Appendix 1 (OUT)). These outliers have characteristics that are similar to one of the defined groups but differ in particular respects (e.g., 10203 could potentially be $\mathrm{Sb}-\mathrm{Mn}$, but has exceptionally high concentrations of manganese; 14072 has low soda but higher alumina and mixed antimony-manganese). There are too few of these to speculate about whether they might indicate the existence of separate compositional groups, or are atypical examples of existing compositions (with one or two elemental anomalies), but they are included in case similar examples are found in future studies.

\section{DISCUSSION}

\section{Recycling and contamination}

By far the largest group represented is the Sb-Mn glass. The range of compositions in this group can be approximated as a mixing line between the contemporary raw glass types in circulation: the Sb colourless glass and the high-Mn glass, illustrated in Figures 1 (a) and 1 (b). This mixing of antimony and high-manganese glasses may be explained through selective recycling. Colourless glass was a valuable raw material, with the Sb colourless glass in particular reserved for finewares. It may therefore be anticipated that glassworkers would recycle colourless glass 
separately wherever possible, combining Sb colourless glass and the high-Mn glass, or using high-Mn glass to extend the antimony colourless glass, even though much of the high-Mn glass often has a slight greyish or greenish tinge. This would explain the incorporation of both antimony and manganese into the glass, and the correlation between these elements. However, the levels of titanium, iron, potassium and copper oxides detected in the Sb-Mn mixed glass are higher than would be expected for a straightforward mixture of the two $\mathrm{Sb}$ and high-Mn raw glass types (Paynter 2006) (Table 1); other factors must be contributing to the overall composition.

Upon subsequent re-melting, all recycled glass including colourless, would gradually spoil by absorbing iron-bearing contaminants, eventually acquiring a blue-green tinge. Experimental work has shown that, during re-melting, glass absorbs aluminium, titanium, potassium and iron oxides from clay crucibles or furnace linings, as well as potassium oxide vapour generated by the furnace fuel, and lesser amounts of calcium, magnesium and phosphorus oxides from settling fuel ashes (Paynter 2008). In addition, fragments of glass-working waste are sometimes strongly coloured by iron oxide scale from the blowing iron. These extraneous materials would ultimately contaminate the glass, which would acquire a stronger blue-green hue. This may lead to the recycled 'colourless' glass becoming blue-green and eventually being used as, and recycled with, blue-green stock, as can be seen in Table 1, where the Sb-Mn glass often has higher concentrations of elements associated with recycling.

The variation in concentration is because these glasses will have different recycling histories, with recycled and raw glass combined in variable proportions an unknown number of times, and so it is not possible to quantify the extent of recycling from the compositions. The amount of crucible and vapour contamination in the glass depends upon the crucible composition, the temperature and time of melting and the number of times the glass has been re-melted (Paynter 2008, 208). Figures 1 (a) and 1 (b) do show, however, that a small number of samples are contaminated by other naturally coloured glasses in circulation at different periods-for example, low-Mn or HIMT (Foster and Jackson 2009)_indicating that some of the glass has probably been recycled at least twice: first as part of a colourless batch and subsequently, once spoiled, as part of a naturally coloured batch. Consequently, the contaminants introduced during repeated recycling, potentially with many different glass compositions, account for the discrepancies between the predicted and actual composition of the $\mathrm{Sb}-\mathrm{Mn}$ mixed glass.

To demonstrate the effect of contamination during recycling, analyses of the Roman glassworking waste (partly melted material, drips and glass from inside melting pots), also from Coppergate, York (Jackson 1992; Jackson et al. 1998, 2003), have been plotted (Figs 3 (a) and 3 (b)), together with the typical composition of the glass-melting crucibles from Coppergate, and the average compositions of Sb colourless glass, high-Mn glass and the mixed Sb-Mn glass. In most of the waste glass and the mixed Sb-Mn glass, the concentrations of aluminium, titanium, potassium, phosphorus and iron oxides are elevated relative to the compositions of the original unaltered colourless glass types in a manner consistent with crucible and fuel vapour contamination. Some of the waste glasses have much higher concentrations of contaminants because they were in direct contact with the crucible wall.

\section{Comparing antimony and manganese decolourized glass}

At Coppergate, high-manganese (high-Mn) glass was used only rarely for high-status vessels, and predominantly during periods when the antimony decolourized glass was scarce; for example, earlier in the first century and then again in the fourth century and later. This pattern is 

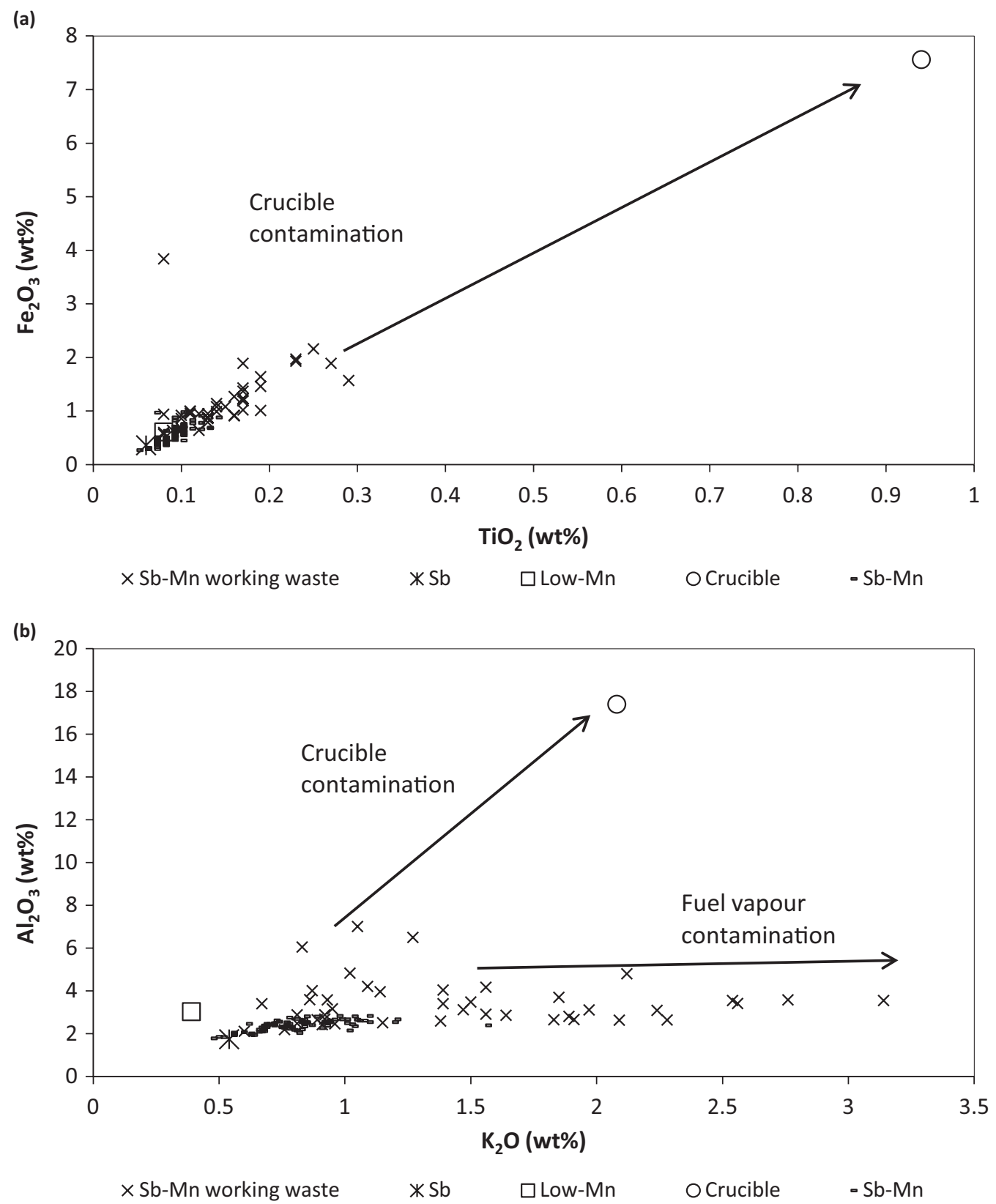

Figure 3 (a) A plot of titanium versus iron oxide for the Roman glass-working waste (Jackson et al. 2003) and the Sb-Mn glass from this study, showing varying levels of crucible contamination. (b) A plot of potassium versus aluminium oxide for the Roman glass waste (Jackson 1992), showing varying levels of contamination from crucibles and fuel vapour. A single data point each shows an average composition for Sb and Low-Mn glass. 
repeated elsewhere (Foy et al. 2003; Foster and Jackson 2009). This may be in part because the colour of high-Mn glass is more variable. While a higher concentration of manganese often produces a colourless glass (see, e.g., Foster and Jackson 2009), it sometimes has a blue-green hue, as is observed in all the high-Mn glasses at Coppergate. The final colour of the high-Mn glass, whether blue-green or colourless, would have been influenced by several factors including the iron oxide and manganese oxide content, and the furnace atmosphere when the glass was last melted, all playing major roles (Bingham and Jackson 2008).

Figure 4 shows the iron and manganese oxide contents of Roman high-Mn glass samples, from the literature and this study, divided according to the final colour of the glass. The colourless high-Mn samples tend to have very low levels of iron oxide (of around $0.3 \mathrm{wt} \%$ or less); conversely, high-Mn samples that contain slightly higher levels of iron oxide (around $0.6 \mathrm{wt} \%$ ) are often a greenish colour, despite manganese oxide being present in excess of $1 \mathrm{wt} \%$. This shows that the colour of the manganese decolourized glass is more sensitive to the iron oxide content, with slightly elevated levels resulting in a blue-green hue.

Therefore, the wide range of blue and green hues observed in the Coppergate high-manganese glass may be because the original batch(es) inadvertently contained slightly higher levels of iron oxide, the colour being more difficult to neutralize with manganese, or because a colourless batch of high-Mn glass was subsequently contaminated during recycling. As a result, the high-Mn glass identified in Britain, which had most probably undergone successive re-melting, is often bluegreen (e.g., Jackson et al. 1991). The same is true of any recycled Sb-Mn glass containing a high-Mn component. In contrast, the antimony decolourized glass remains colourless even with elevated levels of iron oxide; some of the colourless samples reported here (Appendix 1) contain up to $0.8 \mathrm{wt} \%$ iron oxide.

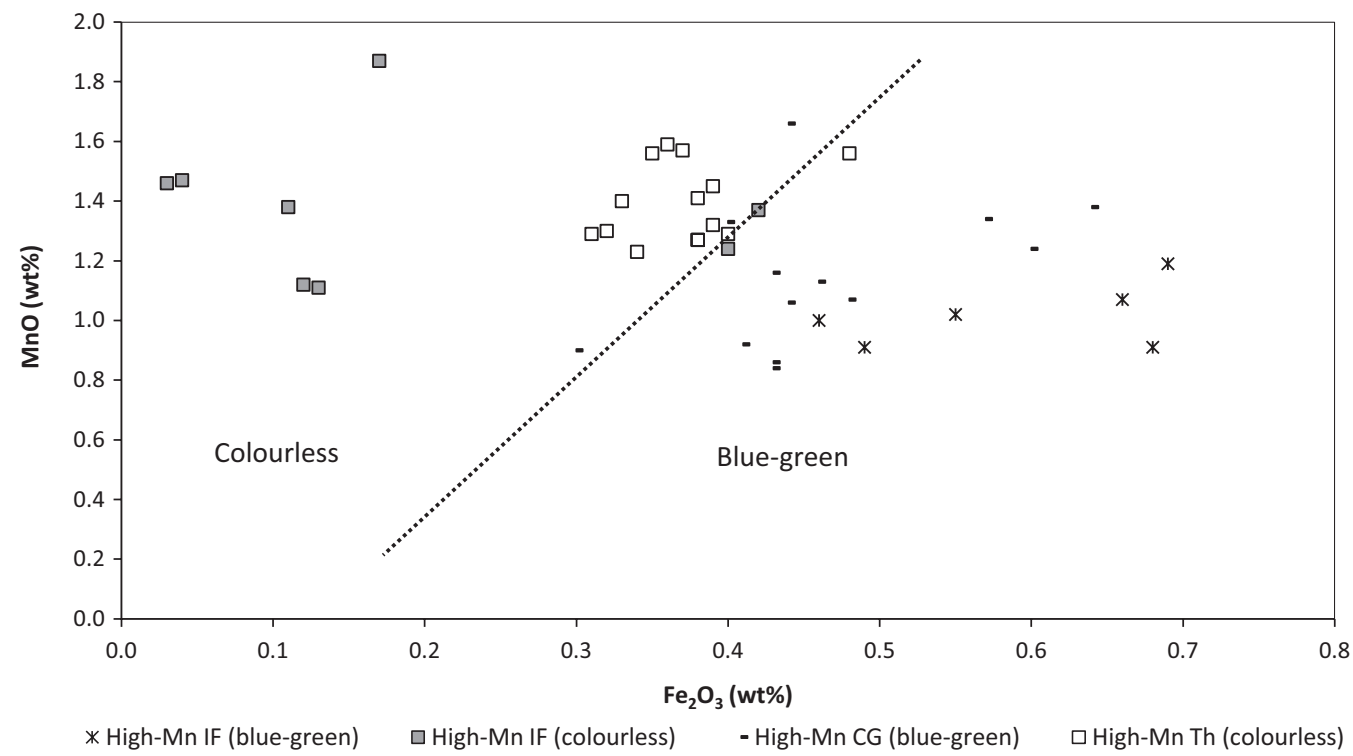

Figure 4 High-Mn glass from Thamusida (Th, Gliozzo et al. 2013), Coppergate (CG, this study) and the Iulia Felix (IF, Silvestri 2008; Silvestri et al. 2008); samples to the top left are visually colourless, whereas samples towards the bottom right are blue-green. 


\section{Glass supply and use through time}

The large and varied Coppergate assemblage includes examples of multiple glass groups, some identified here and others defined previously, but all have parallels elsewhere in Europe. Therefore, the Coppergate glass fits a broader pattern of glass production, circulation and consumption, which changes over time, both in terms of the supply of raw or recycled glasses and the types of vessels used in the Roman world (Appendix 2).

The antimony colourless glass was used for fine tableware; there are no window fragments and only rarely bottles. The samples in this group, such as the faceted beaker dated to the second or third century and the Isings 21 beaker, are of high quality. The data also further illustrate how the $\mathrm{Sb}$ colourless glass composition changes over time, particularly with respect to the diminishing antimony oxide content (Paynter 2006; Paynter and Jackson forthcoming). Previously identified, early variants of antimony colourless glass ( $\mathrm{Sb} / \mathrm{low}-\mathrm{Ca}$ or samples with $>300 \mathrm{ppm}$ of lead) are poorly represented in the assemblage, probably because the majority of the Coppergate antimony glasses are second/third century. There are, however, a number of the late second- and early third-century $\mathrm{Sb}$ samples that contain atypically high levels of lime and alumina, with low levels of antimony (Figs 1 (a) and 1 (b); Appendix 1, 'Sb/high-Ca' samples), which suggests that there may be a chronologically later subgroup as well.

The range of forms seen outside Britain in high-Mn glass-for example, the colourless examples from the Iulia Felix wreck (Silvestri et al. 2008)—suggest that this glass was predominantly used for window glass and bottles up to the third century. The Coppergate assemblage mirrors this, with windows, bottles and jugs, in an extended range of colours. However, by the late third to fourth centuries, more high-quality tablewares are also present in this glass (e.g., Isings 106), and this is also seen in other fourth-century assemblages (Foster and Jackson 2010; Schibille et al. 2012), illustrating a chronological change in the availability of this compositional group over time.

There may also be chronological variation in composition, since later samples in this assemblage (fourth century) contain higher levels of manganese oxide, in some cases in excess of $1 \mathrm{wt} \%$, whereas earlier samples contain less. Glass with similarly high levels of manganese has been reported elsewhere from the late second or early third centuries (Ganio et al. 2012; Gliozzo et al. 2013) onwards, but it seems poorly represented in Britain until a later date, the island receiving only limited supply. The increased incidence of this glass at Coppergate in the fourth century could be related to the scarcity of the Sb colourless glass by this time; hence the need to source an alternative glass for finewares (Paynter and Jackson forthcoming).

No window glass was found in the naturally coloured, low-manganese (low-Mn) glass, but some bottles and a variety of vessels are represented, predominantly tablewares from the first century, including Isings 3 (cast pillar moulded bowls) and Isings 12 (Hofheim cups) forms. Nearly all of the diagnostic fragments are from the first or second centuries. This glass type may represent the blue-green Judean glass mentioned in the edicts of Diocletian, whereas the Sb-glass is more likely to be the glass described as Alexandrian (Barag 1987). In Britain, however, it would seem that the supply of low-Mn glass was limited, and that the recycled $\mathrm{Sb}-\mathrm{Mn}$ glass largely served the same function as the low-Mn glass but was more readily available. Therefore, the mixed Sb-Mn glass becomes dominant in the second and third centuries; it is visually identical and would appear so to the glassworker.

Overall, the most common glass composition amongst the samples was recycled blue-green mixed antimony and manganese glass. Sb-Mn glass is represented in the assemblage by a variety 
of different forms and dates, including cast and blown window glass fragments, a large group of bottles of different styles and a range of blown and cast vessels, including cups, beakers, bowls, jugs and flasks, as well as a hairpin shank. Many fragments in this composition are utilitarian items such as bottles or windows, with a requirement for volume rather than quality. None of the vessels that could be identified represented high-status finds. This compositional group spanned the first to fourth centuries, suggested by the date range of vessel types, including Isings 3 (first century) and Isings 85 (second to mid-third century) (Price and Cottam 1998) and a blown window fragment that may be a fourth-century example. The longevity of the group is not surprising, as it represents a mixed recycled glass that may have included many different compositional groups through time. Interestingly, the range of different types of vessel glass in this group is similar to that for low-Mn blue-green glass and so the two may not have been differentiated on reworking.

The HIMT glass has been used to make cups and beakers, jugs and bottles, and those that could be dated (e.g., Isings 96/106) put this group securely in the fourth century, as anticipated from studies of other late Roman assemblages (Freestone et al. 2005; Foster and Jackson 2009; Jackson and Price 2012). The proportion of each form reflects the composition of glass assemblages in general at this time, when tablewares were more common than bottles. The predominance of HIMT2, the slightly earlier, weaker variant of HIMT, which tends to show more evidence of recycling with other glass compositions, may suggest that when the supply of glass reached northern Britain it had undergone a relatively long life cycle.

Thus the compositional picture, allied to securely dated forms from the site, indicates that glassworkers in Britain had only limited access to raw glass types, whereas recycled glass was readily available. The data also demonstrate that some forms were made more readily with either raw or recycled glass (whether in Britain or elsewhere) or were manufactured in centres that had specific glass supplies.

The new definition of the three groups-namely high-Mn, low-Mn and Sb-Mn glassesallows a more nuanced picture of glass consumption to be realized.

\section{CONCLUSIONS}

The analysis of this assemblage provides a picture of the consumption of Roman glass from the first to fourth centuries in an urban setting and gives greater detail about the different glass compositional groups that were circulating at this time throughout the Roman world, and particularly those reaching Britain. This study confirms that the dominant composition for high-quality colourless tableware was antimony colourless, but that the composition of this glass appears to change chronologically. Compositional subgroups have been identified based on calcium concentrations and the decrease in antimony over time (Paynter 2006; Paynter and Jackson forthcoming). By the late third or early fourth centuries, it appears that there were difficulties sourcing this glass in Britain and elsewhere (Sayre 1963; Foy et al. 2003) since alternatives, such as high-Mn glass and variants of HIMT glass, were increasingly used (Foster and Jackson 2009, 2010; Jackson and Price 2012). At the same time, tin-based opacifiers replace antimony-based ones in opaque glass (Turner and Rooksby 1959), which suggests that the increasing difficulty of obtaining the antimony decolourizer may have been a contributory factor in the rapid decline of antimony colourless glass in the fourth century.

In the first and early second centuries, unaltered raw low-manganese glass makes up a good proportion of the blue-green or greenish glass used more for common tableware and 
storage vessels, but by the later second and third centuries recycled mixed $\mathrm{Sb}-\mathrm{Mn}$ glass dominates.

The high-manganese glass is not well represented in the Coppergate assemblage until the later third and fourth centuries. However, it appears to be common in bottle and window assemblages from the late second and early third centuries in Continental Europe and further afield, and there are some examples from the western provinces in the first century.

A significant finding is the very high number of samples that show clear evidence of recycling. $\mathrm{Sb}-\mathrm{Mn}$ glass, made from a mixture of the antimony colourless and the high-manganese glass, appears to dominate blue-green assemblages in Britain, and was used for everything except the highest-quality tablewares. The high-Mn component of this recycled glass seems relatively uncommon in Britain, so perhaps much of the mixing took place elsewhere to produce $\mathrm{Sb}-\mathrm{Mn}$ recycled glass, which then reached Britain ready-made, although there is ample evidence for glassworkers re-melting and using Sb-Mn glass in Britain (Jackson et al. 1991).

The Coppergate assemblage illustrates how contamination of the glass during recycling by ceramic crucibles, furnace structures and other types of glass influences both the composition and colour of the glass. Some glass which was probably colourless or nearly colourless initially, eventually acquired a blue-green hue. Contaminated blue-green recycled glass was then more likely to be further mixed with other blue-green glass types, such as low-Mn or HIMT, depending on the date. This $\mathrm{Sb}-\mathrm{Mn}$ recycled glass is known to have been melted and worked in Britain, as this composition is seen in the glassworking waste at the sites of Mancetter and Leicester, and it was clearly used for the manufacture of glass-hungry items such as windows and bottles and for more common vessel forms (Jackson et al. 1991). At the extremes of the Roman world in the second and third centuries, this recycled mixture appears to have become more readily available than the raw low-Mn blue-green glass. Since the $\mathrm{Sb}-\mathrm{Mn}$ composition resulted from the dilution and recycling of antimony decolourized glass, it follows the same pattern of decline in the fourth century; HIMT glass, which is also often recycled, becomes increasingly common in its place.

The assemblage from Coppergate therefore illustrates the different compositional types reaching the western edges of the Roman world, but also how the composition and appearance of glass changes once it has been through more than one 'great big melting pot'. The recycled antimony-manganese glass makes up more than $40 \%$ of the analysed glass. This has important implications for trace element and isotopic analysis, because if the chemical composition of the glass has been affected by glass mixing, ceramic crucibles and furnace materials, then the trace element and isotopic composition of the glass is likely to have been affected too. As one referee suggests, the 'big melting pot' is not entirely homogenizing all of the glass, and compositional groups can still be identified. However, these groups are the dominant primary glasses reaching their market in that particular period and as such recycling becomes almost invisible, because like is being mixed with like. It is clear from the data set that much of the glass is reused, perhaps over many years, providing a large reservoir for re-melting, against which rarer compositional groups, perhaps made on a smaller scale, traded less extensively or in decline, are more difficult to detect-for example, the products of the subordinate glass manufacturing centres referred to by Pliny the Elder (Eichholz 1962), or plant-ash glass types that may be the products of an earlier glass industry. These glasses, introduced into the recycling pool, would soon become diluted to the extent that they were difficult to recognize. Thus an appreciation of the scale and effects of recycling is key to understanding manufacturing locations and glass compositional groups. 


\section{ACKNOWLEDGEMENTS}

This project was funded by the Science and Engineering Research Council in the form of a Ph.D. grant to CMJ (SERC 88803864), and supervised by Dr S. E. Warren and Professor J. R. Hunter of the Department of Archaeological Science, University of Bradford, UK. Help with chemical analysis was kindly provided by Drs J. N. Walsh and S. James of the then NERC ICP-AES facility at Royal Holloway University of London, UK. York Archaeological Trust, especially Dr A. Mainman, are thanked for the loan of the study material. Dr H. E. M. Cool is acknowledged and thanked for the typological assessment. Apologies to Blue Mink for mangling their song title. 


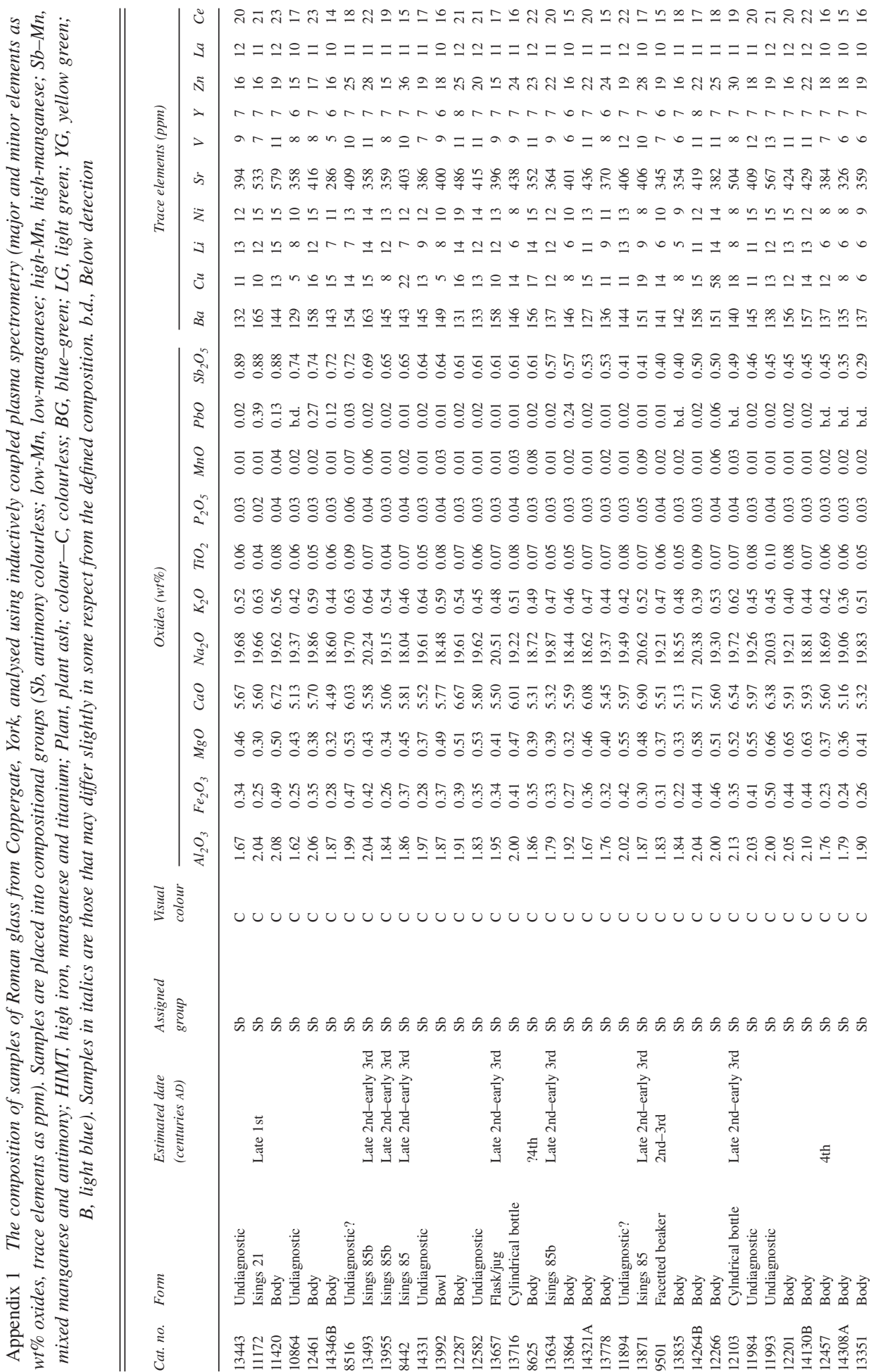




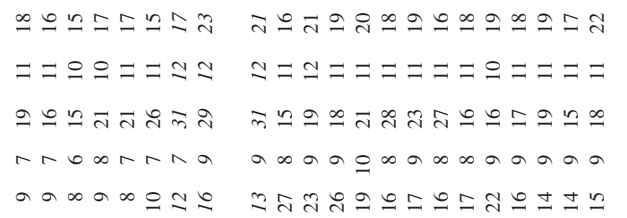

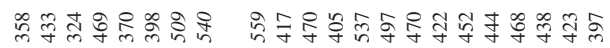

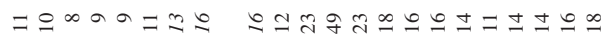

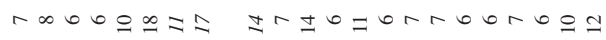

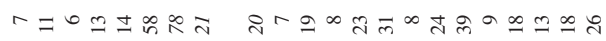

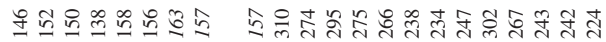

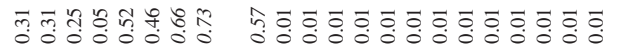

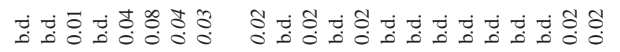

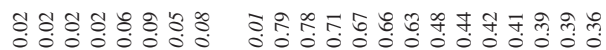

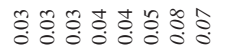

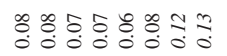

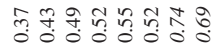

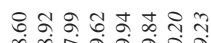

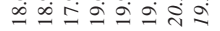

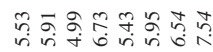

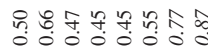

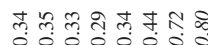

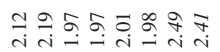

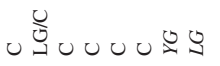

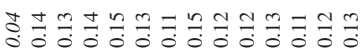

ริ웅ㅇㅇㅇㅇㅇㅇㅇㅇㅇㅇㅇㅇㅇㅇㅇ

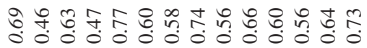

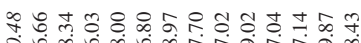

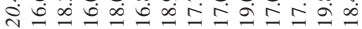

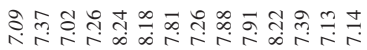

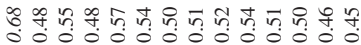

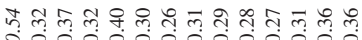

ㅇำ 든

U్

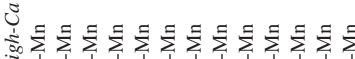

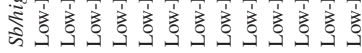

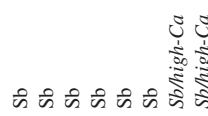

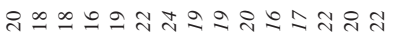

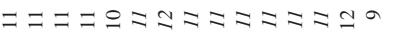

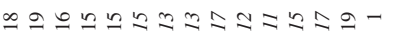

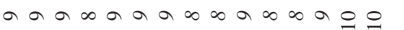

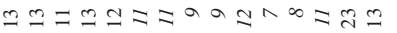

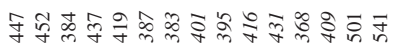

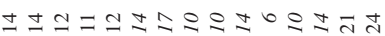

$\infty 60-6= \pm 60 \geqslant 6 \infty \pm 0$ 의

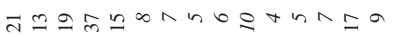

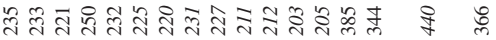

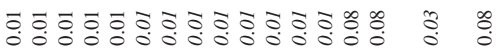

نำ

শై

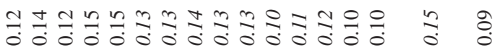

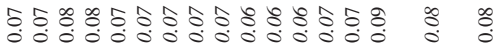

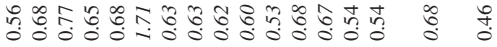

Ұ

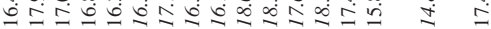

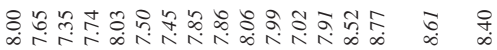

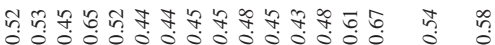

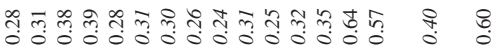

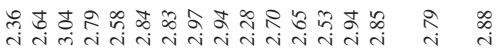

$\sqcap \sqcap \sqcap \sqcap \sqcap \searrow \circlearrowright$

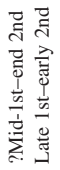

品

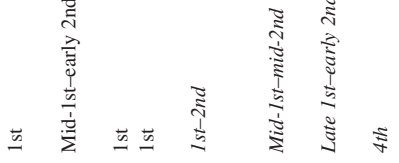

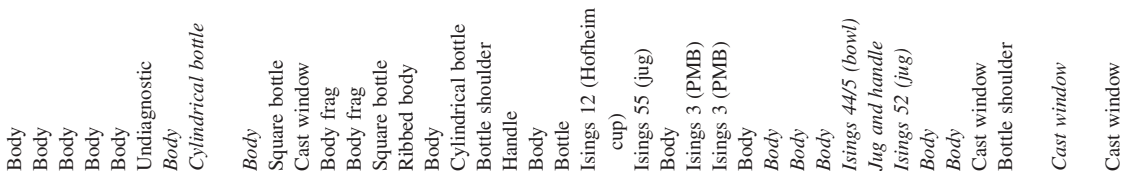

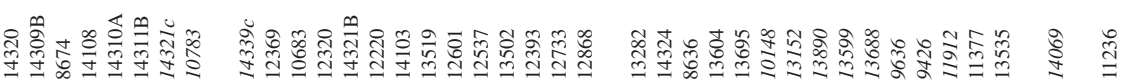




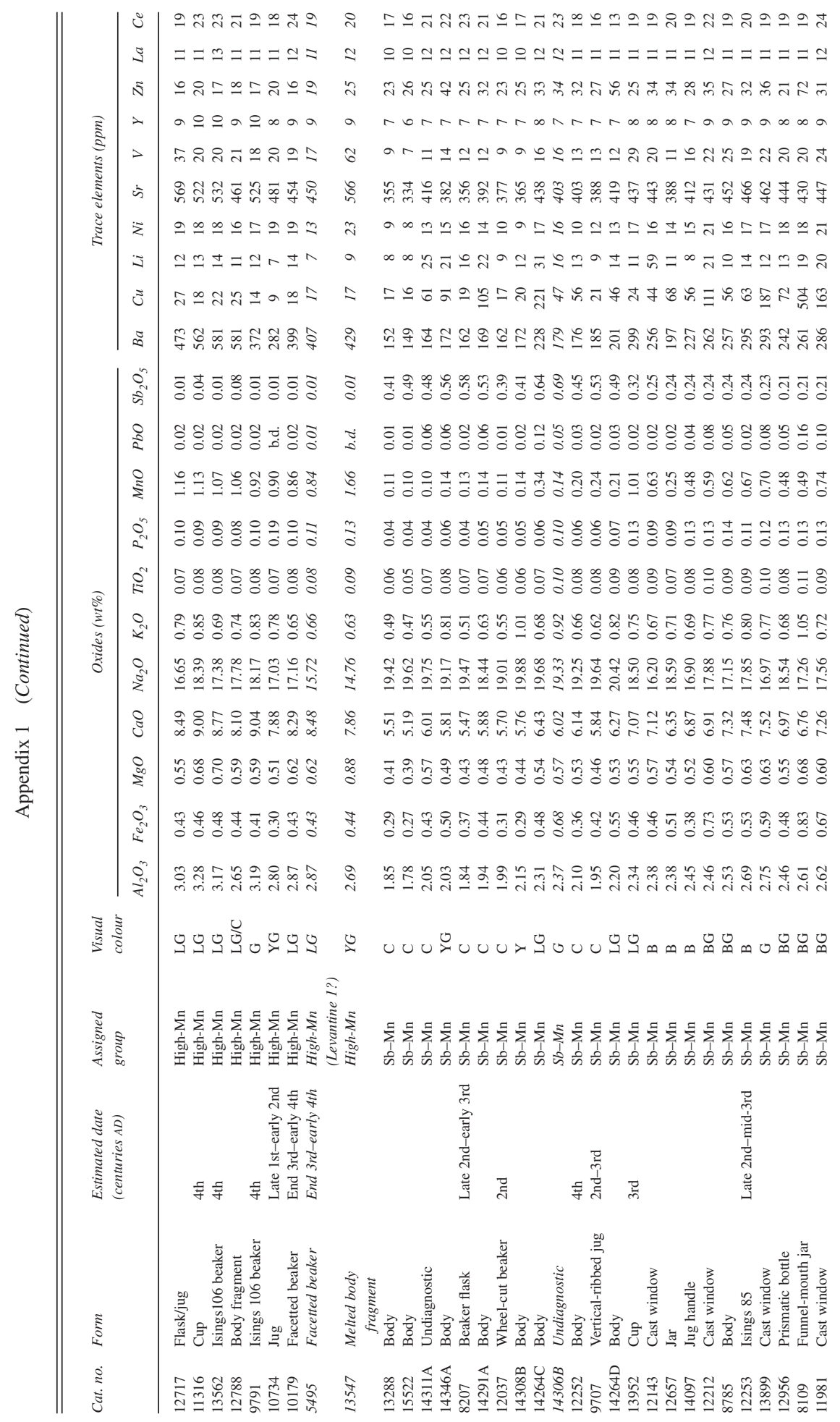




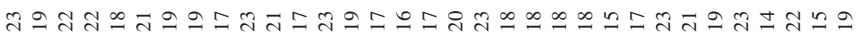

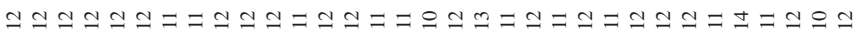

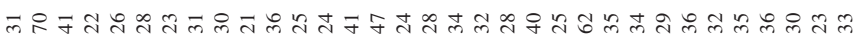

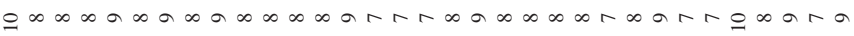
유ำ

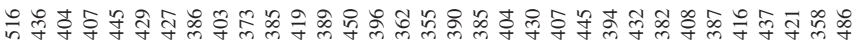
สํำ

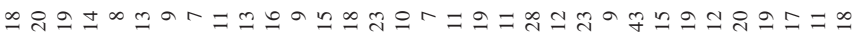

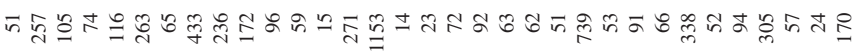

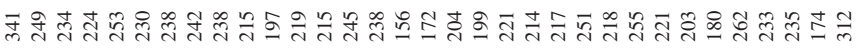

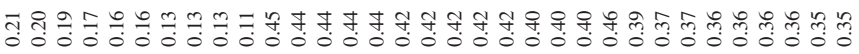

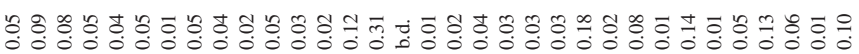

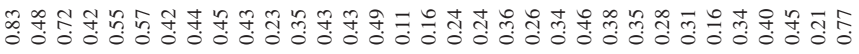

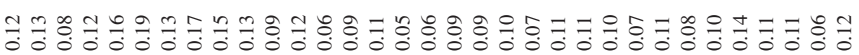

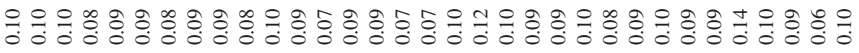

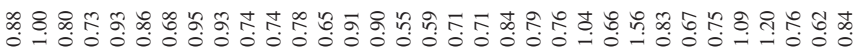

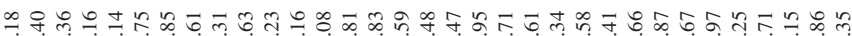

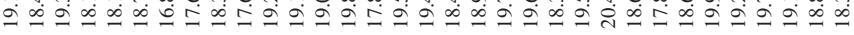

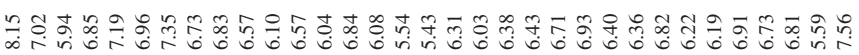

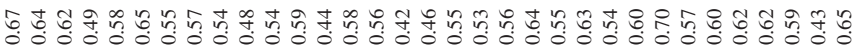

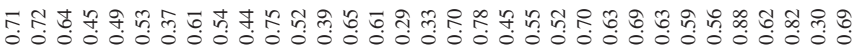

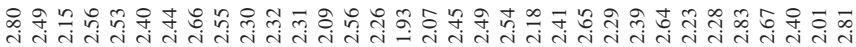

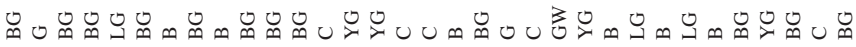

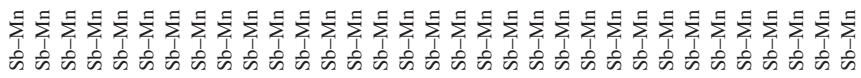

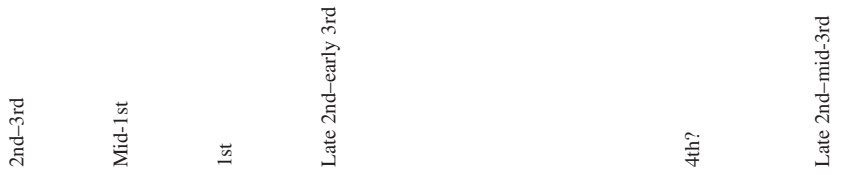

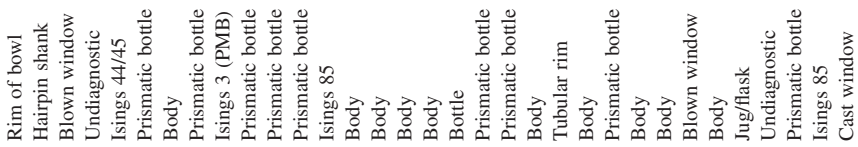

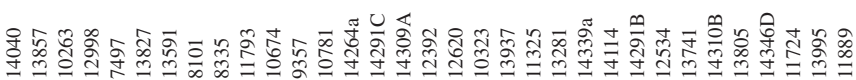




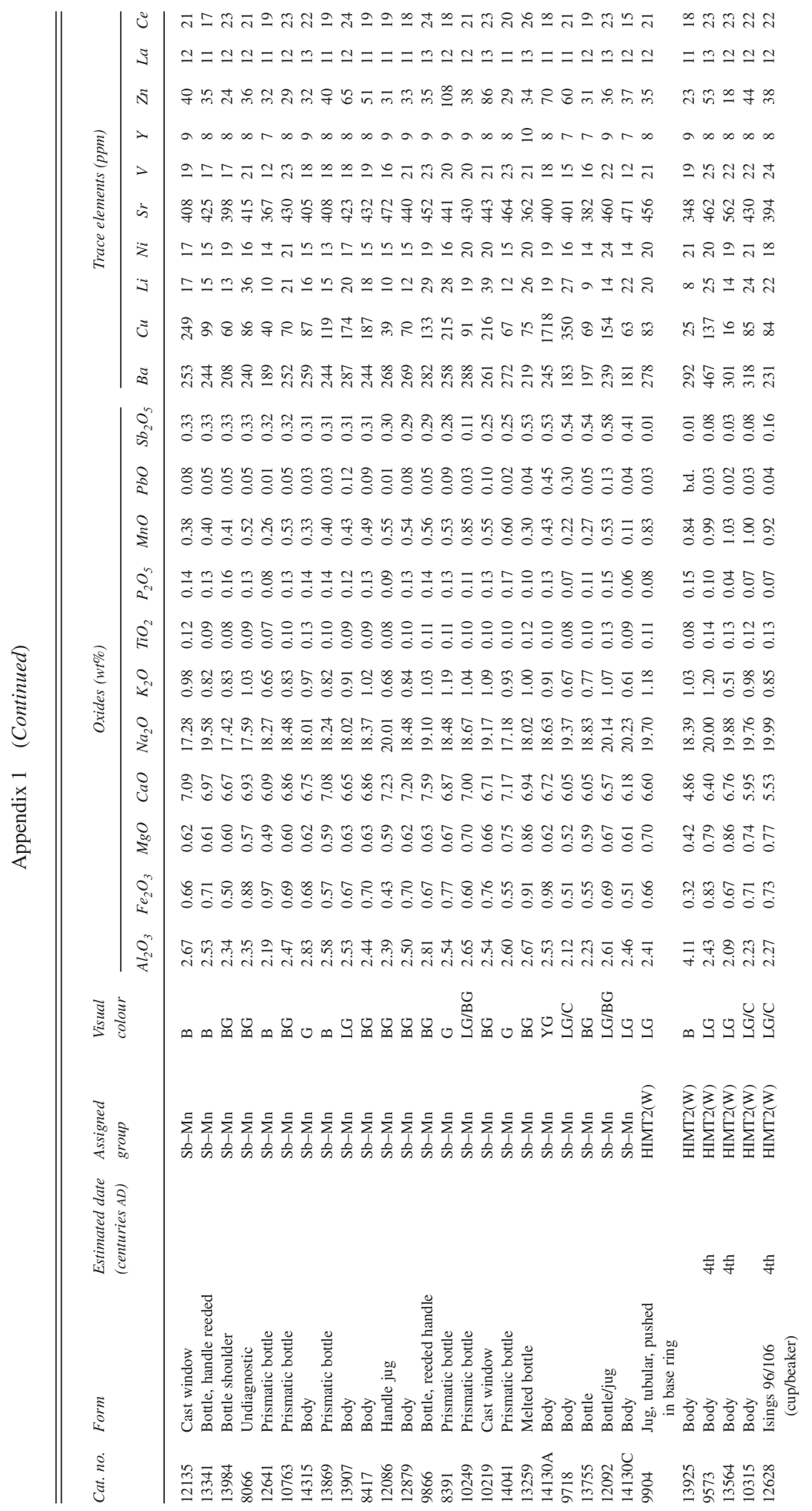




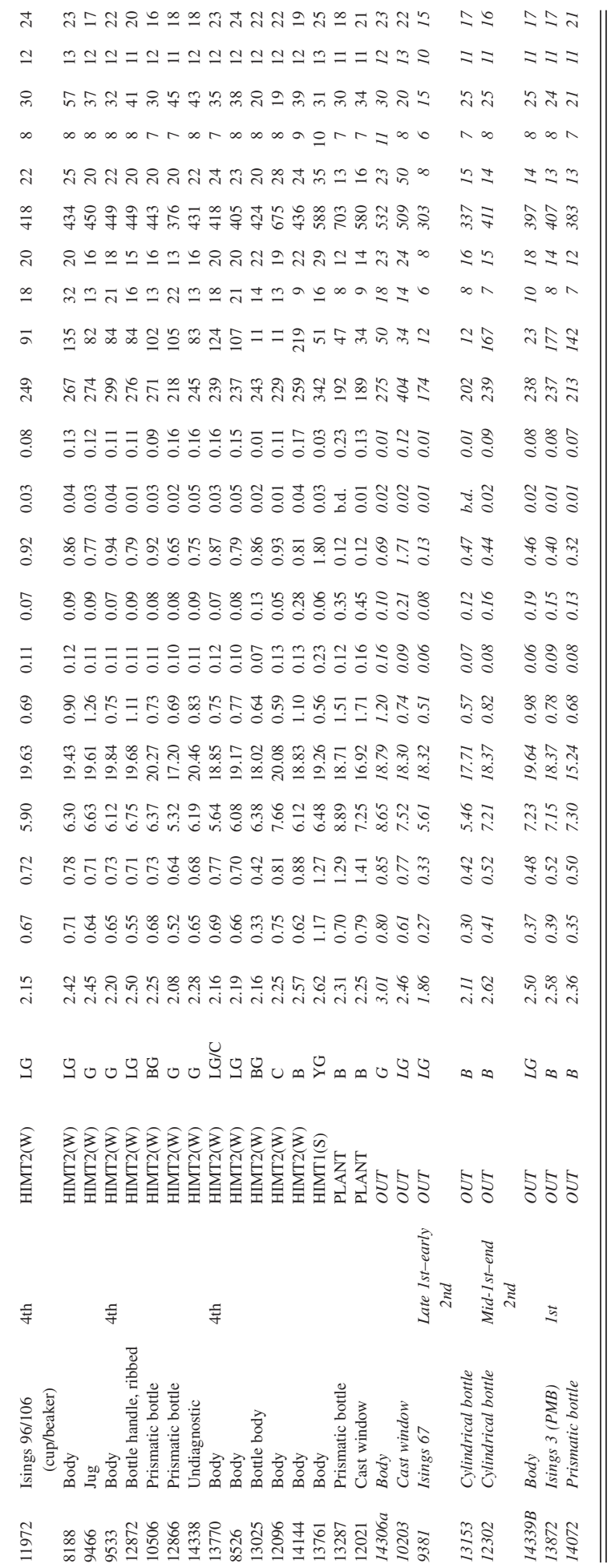


Appendix 2 Correspondence between compositional groups for first- to fourth-century glass from selected studies, and representative compositions as wt\% oxides unless stated otherwise (Ba and $\mathrm{Cu}$ as ppm). (nm, not measured, below detection or not quoted): *indicates mean affected by one or two very high or low values

\begin{tabular}{|c|c|c|c|c|c|}
\hline Decolourizer & Major elements & Known as & References & Site/region & $\begin{array}{l}\text { Approx. date } \\
\text { (mostly centuries } \\
A D)\end{array}$ \\
\hline
\end{tabular}

Antimony (Sb) (colourless) High soda, low lime,
low alumina

Antimony (high) High soda, very low lime, alumina and barium

alumina and barium

Low-manganese (low-Mn) (blue-green)

Manganese (low) Low soda, high lime, high alumina
Antimony low lime (Sb/low-Ca) (colourless)

$\begin{array}{llll}\text { Group 4 } & \text { Foy et al. (2004) } & \text { Egypt, France, Tunisia } & \text { 1st to mid-3rd } \\ \text { Antimony only } & \text { Paynter (2006) } & \begin{array}{c}\text { Binchester, Colchester, } \\ \text { Lincoln }\end{array} \\ & \text { Silvestri } \text { et al. } \text { (2008) } 3 \text { rd } \\ \text { CL1 } & \begin{array}{l}\text { Iulia Felix } \\ \text { York, Mancetter, }\end{array} & \text { 3rd } \\ \text { Group 1a } & \text { Jackson (2005) } & \text { Leicester } & \text { 2nd-3rd) } \\ & & \text { Adria, Italy } & \text { 2nd } \\ \text { N2 (selection) } & \text { Gallo } \text { et al. (2013) } & \text { South Shields } & \text { 3rd-4th } \\ \text { Colourless } & \text { Jackson and Price (2012) } & \text { UK various } & \text { 3rd-4th } \\ \text { Colourless 1 } & \text { Foster and Jackson (2010) } & \text { Urd } & \text { 1st-3rd }\end{array}$

Lot A Foy et al. (2004) Carthage and France Hellenistic

Low-barium Paynter (2006)

Included in N2 Gallo et al. (2013)

Facet-cut (some) Baxter et al. (2005)

Paynter and Jackson (in prep.) British sites 1 st-3rd

Group $3 \quad$ Foy et al. (2000)

Gliozzo et al. (2013)

Gallo et al. (2013)

Jackson (1994)

Jackson (1992)

Jackson (1994)

Jackson (1992)

High-manganese (high-Mn) (varying from colourless to blue-green)

Manganese (high) Low soda, high lime,

Group 2b

Silvestri et al. (2008)

CL2

Ganio et al. (2012)

Jackson (1994)

Levantine 1a Foster and Jackson (2009)

2b Meek (2013)

Petra 2

Schibille et al. (2012)

Gliozzo et al. (2013)

ADN1

Gallo et al. (2013)

Manganese low lime (Mn/low-Ca) (colourless)

Manganese High soda, lower alumin

lime and barium

$2 \mathrm{a}$

Meek (2013)

$2 \mathrm{a}$

Foster and Jackson (2010)

Group $3.2 \quad$ Foy et al. (2003)

Mixed antimony and manganese ( $\mathrm{S} b-\mathrm{Mn})$ (varying from blue-green to colourless)

Manganese and antimony Intermediate soda and lime, Group 2a Jackson (2005)

sometimes elevated iron,

alumina, potassium and copper

Cu blue-green Paynter (2006)

Group 2a Jackson (2005)

CL1/2 Silvestri et al. (2008)

Colourless $3 \quad$ Foster and Jackson (2010)

Jackson (1994)

N2 (part of)

Group 2a

Binchester, Colchester, Mid-1st-mid-2nd

\section{Lincoln}

Adria, Italy 2nd
Jackson (2005) Coppergate

$\begin{array}{ll}\text { Thamusida, Morocco } & \text { 2nd-3rd } \\ \text { Adria, Italy } & \text { 1st } \\ \text { Mancetter } & \text { 2nd-3rd } \\ \text { Coppergate } & \text { 1st-3rd } \\ \text { Leicester } & \text { 2nd-3rd }\end{array}$

Coppergate

1st-4th, mainly

Iulia Felix

Embiez

Mancetter

UK various

UK

Petra

2nd-3rd

3 rd

Late 2nd-early 3rd

2nd-3rd

4 th

4th-7th

2nd-3rd

1 st

Unprovenanced $\quad 3$ rd-7th

UK

4 th

France 4th-5th

Leicester $\quad 3$ rd

Binchester, Lincoln, Mid-1st-3rd

Colchester

York

Iulia Felix

UK various

Mancetter

Adria, Italy

2nd-3rd

3rd

4 th

2nd-3rd

3rd

2nd-4th

Paynter and Jackson (in prep.) British sites

1 st-3rd 


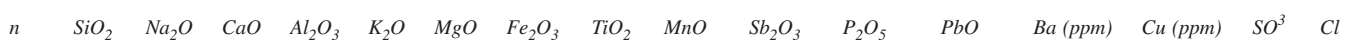

\begin{tabular}{|c|c|c|c|c|c|c|c|c|c|c|c|c|c|c|c|c|}
\hline 94 & 71 & 19.05 & 5.56 & 1.94 & 0.42 & 0.43 & 0.34 & 0.06 & 0.02 & 0.63 & 0.02 & $\mathrm{~nm}$ & $\mathrm{~nm}$ & $\mathrm{~nm}$ & $\mathrm{~nm}$ & $\mathrm{~nm}$ \\
\hline 167 & $\mathrm{~nm}$ & 18.90 & 5.67 & 2.01 & 0.43 & 0.41 & 0.37 & 0.06 & 0.02 & 0.43 & 0.05 & 0.04 & 148 & 12 & $\mathrm{~nm}$ & $\mathrm{~nm}$ \\
\hline 60 & 70.15 & 19.80 & 4.80 & 2.00 & 0.4 & 0.4 & 0.40 & 0.07 & bd & 0.8 & 0.03 & $<0.01$ & 118 & 18 & 0.3 & 1.4 \\
\hline 53 & $\mathrm{~nm}$ & 19.34 & 5.63 & 1.91 & 0.5 & 0.45 & 0.35 & 0.07 & 0.04 & 0.5 & 0.04 & 0.04 & 148 & 17 & $\mathrm{~nm}$ & $\mathrm{~nm}$ \\
\hline 3 & 69.2 & 18.84 & 5.44 & 1.87 & 0.46 & 0.51 & 0.40 & 0.08 & 0.09 & 0.53 & 0.04 & $<0.01$ & 134 & 9 & 0.31 & 1.6 \\
\hline 23 & $\mathrm{~nm}$ & 18.93 & 5.62 & 1.79 & 0.42 & 0.51 & 0.39 & 0.07 & 0.03 & 0.46 & 0.02 & bd & 138 & 23 & $\mathrm{~nm}$ & $\mathrm{~nm}$ \\
\hline 46 & $\mathrm{~nm}$ & 18.99 & 5.74 & 1.90 & 0.39 & 0.49 & 0.40 & 0.06 & 0.04 & 0.35 & 0.02 & 0.01 & 148 & 23 & $\mathrm{~nm}$ & $\mathrm{~nm}$ \\
\hline 70 & $\mathrm{~nm}$ & 18.70 & 5.70 & 1.90 & 0.5 & 0.4 & 0.40 & 0.06 & bd & 0.9 & 0.04 & 0.06 & 131 & 13 & $\mathrm{~nm}$ & $\mathrm{~nm}$ \\
\hline 2 & 74.7 & 18.00 & 4.09 & 1.12 & 0.56 & 0.55 & 0.40 & 0.075 & bd & 2.97 & bd & 1.30 & $\mathrm{~nm}$ & $\mathrm{~nm}$ & $\mathrm{~nm}$ & $\mathrm{~nm}$ \\
\hline 9 & $\mathrm{~nm}$ & 18.52 & 4.51 & 1.53 & 0.61 & 0.40 & 0.43 & 0.06 & 0.06 & 0.96 & 0.05 & 0.26 & 85 & 16 & $\mathrm{~nm}$ & $\mathrm{~nm}$ \\
\hline 1 & 70.25 & 17.13 & 4.22 & 1.48 & 0.75 & 0.44 & 0.51 & 0.10 & 0.16 & 1.14 & 0.04 & 0.11 & $<10$ & 151 & $\mathrm{~nm}$ & $\mathrm{~nm}$ \\
\hline 10 & $\mathrm{~nm}$ & 17.77 & 3.96 & 1.30 & 0.58 & 0.43 & 0.51 & 0.09 & 0.05 & 2.20 & 0.06 & 0.44 & 87 & $33 *$ & $\mathrm{~nm}$ & $\mathrm{~nm}$ \\
\hline 3 & $\mathrm{~nm}$ & 18.36 & 4.09 & 1.39 & 0.55 & 0.34 & 0.37 & 0.04 & 0.02 & 2.51 & 0.04 & 0.35 & 74 & 18 & $\mathrm{~nm}$ & $\mathrm{~nm}$ \\
\hline 22 & 69.80 & 17.00 & 8.01 & 2.54 & 0.61 & 0.61 & 0.54 & 0.06 & 0.63 & $\mathrm{~nm}$ & 0.23 & $\mathrm{~nm}$ & $\mathrm{~nm}$ & $\mathrm{~nm}$ & $\mathrm{~nm}$ & $\mathrm{~nm}$ \\
\hline 9 & 70.52 & 14.92 & 8.18 & 2.57 & 0.53 & 0.49 & 0.60 & 0.06 & 0.29 & $11 \mathrm{ppm}$ & 0.12 & $12 \mathrm{ppm}$ & $\mathrm{nm}$ & 10 & 0.09 & $\mathrm{~nm}$ \\
\hline 13 & 69.02 & 17.55 & 7.71 & 2.51 & 0.64 & 0.51 & 0.40 & 0.06 & 0.50 & 0.06 & 0.13 & $61 \mathrm{ppm}$ & $\mathrm{nm}$ & 98 & 0.20 & 1.4 \\
\hline 32 & $\mathrm{~nm}$ & 16.70 & 7.70 & 2.48 & 0.64 & 0.52 & 0.40 & 0.07 & 0.39 & 0.02 & 0.14 & 0.01 & 236 & 28 & $\mathrm{~nm}$ & $\mathrm{~nm}$ \\
\hline 27 & $\mathrm{~nm}$ & 17.59 & 7.65 & 2.66 & 0.71 & 0.50 & 0.32 & 0.07 & 0.30 & 0.02 & 0.13 & 0.01 & 236 & 32 & $\mathrm{~nm}$ & $\mathrm{~nm}$ \\
\hline 5 & $\mathrm{~nm}$ & 17.54 & 7.44 & 2.40 & 0.60 & 0.61 & 0.47 & 0.09 & 0.20 & 0.01 & 0.12 & 0.01 & 210 & 10 & $\mathrm{~nm}$ & $\mathrm{~nm}$ \\
\hline 16 & $\mathrm{~nm}$ & 16.85 & 8.24 & 2.86 & 0.65 & 0.60 & 0.44 & 0.08 & 1.07 & 0.03 & 0.12 & 0.01 & 406 & 17 & $\mathrm{~nm}$ & $\mathrm{~nm}$ \\
\hline 12 & 70.29 & 15.20 & 7.80 & 2.60 & 0.5 & 0.6 & 0.20 & 0.07 & 1.40 & bd & 0.14 & $21 \mathrm{ppm}$ & 369 & 17 & 0.10 & 1.2 \\
\hline 5 & 65.27 & 15.55 & 8.44 & 2.26 & 0.54 & 0.45 & 0.28 & 0.05 & 1.35 & 0.16 & 0.16 & $\mathrm{~nm}$ & 433 & $\mathrm{~nm}$ & $\mathrm{~nm}$ & $\mathrm{~nm}$ \\
\hline 2 & $\mathrm{~nm}$ & 14.93 & 7.86 & 2.51 & 0.71 & 0.63 & 0.49 & 0.08 & 1.20 & 0.03 & 0.18 & 0.01 & 286 & 25 & $\mathrm{~nm}$ & $\mathrm{~nm}$ \\
\hline 16 & $\mathrm{~nm}$ & 15.55 & 8.45 & 2.81 & 0.6 & 0.59 & 0.42 & 0.07 & 1.23 & 0.06 & 0.09 & $<0.01$ & 383 & 20 & $\mathrm{~nm}$ & $\mathrm{~nm}$ \\
\hline 3 & 70.1 & 15.67 & 8.70 & 3.02 & 0.67 & 0.65 & 0.44 & 0.06 & 1.17 & $\mathrm{~nm}$ & $\mathrm{~nm}$ & $\mathrm{~nm}$ & $\mathrm{bm}$ & $\mathrm{nm}$ & $\mathrm{nm}$ & $\mathrm{nm}$ \\
\hline 18 & 68.45 & 16.13 & 8.16 & 2.73 & 1.04 & 0.46 & 0.36 & 0.07 & 1.08 & 0.02 & 0.15 & $<0.01$ & 308 & 59 & 0.17 & 0.9 \\
\hline 14 & 71.94 & 14.16 & 7.60 & 2.31 & 0.45 & 0.51 & 0.37 & 0.06 & 1.39 & 110 & 0.14 & 12 ppm & $\mathrm{nm}$ & 8 & 0.05 & $\mathrm{~nm}$ \\
\hline 2 & 68.54 & 18.04 & 7.63 & 2.50 & 0.77 & 0.64 & 0.38 & 0.05 & 1.05 & $\mathrm{~nm}$ & 0.10 & $10 \mathrm{ppm}$ & 283 & 23 & 0.31 & 1.2 \\
\hline 3 & 67.42 & 18.81 & 6.41 & 2.36 & 0.53 & 0.73 & 0.63 & 0.09 & 0.97 & $\mathrm{~nm}$ & $\mathrm{~nm}$ & $\mathrm{~nm}$ & $\mathrm{~nm}$ & $\mathrm{~nm}$ & $\mathrm{~nm}$ & 1.3 \\
\hline 5 & $\mathrm{~nm}$ & 18.46 & 5.77 & 1.81 & 0.29 & 0.67 & 0.48 & 0.09 & 1.14 & 0.06 & 0.03 & bd & 199 & 14 & $\mathrm{~nm}$ & $\mathrm{~nm}$ \\
\hline 17 & 68.07 & 18.79 & 7.05 & 1.92 & 0.44 & 0.65 & 0.70 & 0.09 & 0.89 & 18 & 0.08 & 179 ppm & 243 & 25 & $\mathrm{~nm}$ & $\mathrm{~nm}$ \\
\hline 70 & $\mathrm{~nm}$ & 18.50 & 6.36 & 2.33 & 0.70 & 0.54 & 0.67 & 0.10 & 0.26 & 0.40 & 0.11 & 0.04 & 201 & 82 & $\mathrm{~nm}$ & $\mathrm{~nm}$ \\
\hline 18 & $\mathrm{~nm}$ & 19.44 & 5.68 & 2.21 & 0.54 & 0.48 & 0.49 & 0.09 & 0.26 & 0.51 & 0.08 & 0.04 & 179 & 22 & $\mathrm{~nm}$ & $\mathrm{~nm}$ \\
\hline 11 & $\mathrm{~nm}$ & 19.25 & 6.10 & 2.28 & 0.71 & 0.56 & 0.54 & 0.10 & 0.34 & 0.46 & 0.10 & 0.07 & 207 & 116 & $\mathrm{~nm}$ & $\mathrm{~nm}$ \\
\hline 13 & 69.13 & 19.02 & 5.64 & 2.14 & 0.54 & 0.66 & 0.64 & 0.12 & 0.19 & 0.79 & 0.07 & 83 ppm & 144 & 24 & 0.28 & 1.3 \\
\hline 69 & $\mathrm{~nm}$ & 19.48 & 6.12 & 2.08 & 0.53 & 0.59 & 0.55 & 0.09 & 0.35 & 0.04 & 0.05 & 0.07 & 219 & 121 & $\mathrm{~nm}$ & $\mathrm{~nm}$ \\
\hline 64 & $\mathrm{~nm}$ & 18.08 & 6.63 & 2.41 & 0.73 & 0.54 & 0.52 & 0.09 & 0.43 & 0.28 & 0.13 & 0.04 & 223 & 76 & $\mathrm{~nm}$ & $\mathrm{~nm}$ \\
\hline 1 & 68.28 & 18.49 & 6.38 & 2.16 & 0.55 & 0.53 & 0.46 & 0.08 & 0.54 & 0.41 & 0.09 & 0.01 & 195 & 155 & $\mathrm{~nm}$ & $\mathrm{~nm}$ \\
\hline 87 & $\mathrm{~nm}$ & 18.70 & 6.57 & 2.39 & 0.81 & 0.57 & 0.58 & 0.09 & 0.40 & 0.35 & 0.10 & 0.06 & 228 & 151 & $\mathrm{~nm}$ & $\mathrm{~nm}$ \\
\hline 6 & $\mathrm{~nm}$ & 19.21 & 5.51 & 2.14 & 0.60 & 0.46 & 0.51 & 0.10 & 0.27 & 0.90 & 0.08 & 0.05 & 171 & 60 & $\mathrm{~nm}$ & $\mathrm{~nm}$ \\
\hline
\end{tabular}


Appendix 2 (Continued)

\begin{tabular}{|c|c|c|c|c|c|}
\hline Decolourizer & Major elements & Known as & References & Site/region & $\begin{array}{l}\text { Approx. date } \\
\text { (mostly centuries } \\
A D)\end{array}$ \\
\hline \multicolumn{6}{|c|}{ Levantine I (blue-green) } \\
\hline \multirow[t]{3}{*}{ None } & Low soda, high alumina and lime & & Jackson (1994) & Mancetter & $3 \mathrm{rd}-4$ th \\
\hline & & Levantine $1 b$ & Foster and Jackson (2009) & Various UK & 4 th \\
\hline & & Levantine & Freestone et al. (2000) & Dor, Appollonia & 6 th-7th \\
\hline \multicolumn{6}{|c|}{ HIMT (olive green) } \\
\hline \multirow[t]{7}{*}{ Manganese } & $\begin{array}{l}\text { High soda, low lime, } \\
\text { high titanium and iron }\end{array}$ & HIMT2 & Foster and Jackson (2009) & UK & 4 th \\
\hline & & HIMT1 & Foster and Jackson (2009) & UK & 4 th \\
\hline & & Group 1 & Foy et al. (2003) & France, Tunisia and Egypt & 5 th \\
\hline & & HIMT London & Freestone et al. (2005) & London & 4 th \\
\hline & & HIMT Carthage & Freestone et al. (2005) & Carthage & 4 th \\
\hline & & HIMT1 & Jackson and Price (2012) & South Shields & 4th \\
\hline & & HIMT2 & Jackson and Price (2012) & South Shields & 4 th \\
\hline \multicolumn{6}{|c|}{ Plant ash (blue-green) } \\
\hline \multirow[t]{6}{*}{ Manganese } & High potassium, high magnesium & Plant ash glass & Jackson et al. (2009) & Colchester & $1 \mathrm{st}$ \\
\hline & & & Gallo et al. (2013) & Adria, Italy & $1 \mathrm{st}$ \\
\hline & & & Henderson (1996) & Fishbourne & $1 \mathrm{st}$ \\
\hline & & & Thirion-Merle (2005) & GdeFoss/Ruscino & $1 \mathrm{st}$ \\
\hline & & & Jackson and Cottam (forthcoming) & Barzan, France & $1 \mathrm{st}$ \\
\hline & & & Jackson and Cottam (forthcoming) & Ribnica, Slovenia & $1 \mathrm{st}$ \\
\hline
\end{tabular}

\section{REFERENCES}

Arletti, R., Vezzalini, G., Biaggio Simona, S., and Maselli Scotti, F., 2008, Archaeometrical studies of Roman Imperial age glass from Canton Ticino, Archaeometry, 50, 606-26.

Barag, D., 1987, Recent important epigraphic discoveries related to the history of glassmaking in the Roman period, in Annales du $10^{e}$ Congrès de l'Association internationale pour l'histoire du verre: Madrid-Segovie, 23-28 septembre 1985, 109-16, AIHV, Amsterdam.

Baxter, M. J., Cool, H. E. M., and Jackson, C. M., 2005, Further studies in the compositional variability of colourless Romano-British vessel glass, Archaeometry, 47, 47-68.

Bingham, P. A., and Jackson, C. M., 2008, Roman blue-green bottle glass: chemical-optical analysis and high temperature viscosity modelling, Journal of Archaeological Science, 35, 302-9.

Brems, D., and Degryse, P., 2014, Trace element analyses in provenancing Roman glass-making, Archaeometry, 56, Supplement S1, 116-36; DOI: 10.1111/arcm.12063

Brill, R. H., 1988, Scientific investigations of the Jalame glass and related finds, in Excavations at Jalame: site of a glass factory in late Roman Palestine (ed. G. D. Weinberg), 257-94, University of Missouri Press, Columbia, NY.

Eichholz, D. E., 1962, Pliny, Natural history, vol. X, books XXXVI and XXXVII, 153, Heinemann, London.

Foster, H., and Jackson, C. M., 2009, The composition of 'naturally coloured' late Roman vessel glass from Britain and the implications for models of glass production and supply, Journal of Archaeological Science, 36, 189-204.

Foster, H., and Jackson, C. M., 2010, The composition of late Romano-British colourless vessel glass: glass production and consumption, Journal of Archaeological Science, 37, 3068-80.

Foy, D., Thirion-Merle, V., and Vichy, M., 2004, Contribution à l'étude des verres antiques décolorés à l'antimoine, Revue d'Archéométrie, 28, 169-77.

Foy, D., Vichy, M., and Picon, M., 2000, L'ingots de verre en Méditerranée occidentale (III ${ }^{\mathrm{e}}$ siècle av. J.-C. - VII ${ }^{\mathrm{e}}$ siècle ap. J.-C.), in Annales du $14^{e}$ Congrès de l'Association Internationale pour l'Histoire de Verre: Italia/Venezia-Milano, 51-7, AIHV, Amsterdam.

Foy, D., Picon, M., Vichy, M., and Thirion-Merle, V., 2003, Caractérisation des verres de la fin de l'Antiquité en Méditerranée occidentale: l'émergence de nouveaux courants commerciaux, in Echanges et commerce du verre dans le monde antique, Actes du colloque international de l'AFAV, Aix-en-Provence et Marseille 2001 (eds. D. Foy and M.-D. Nenna), 41-86, Monographies Instrumentum 24, Éditions Monique Mergoil, Montagnac. 


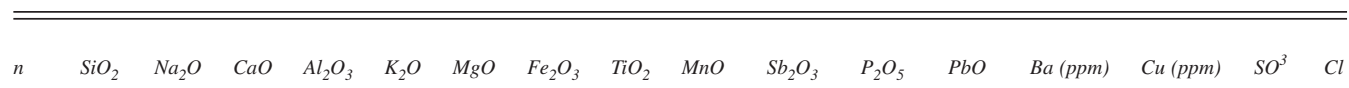

\begin{tabular}{|c|c|c|c|c|c|c|c|c|c|c|c|c|c|c|c|c|}
\hline 5 & $\mathrm{~nm}$ & 16.74 & 8.72 & 2.46 & 0.67 & 0.56 & 0.39 & 0.07 & 0.04 & 0.01 & 0.14 & 0.01 & 206 & 5 & $\mathrm{~nm}$ & $\mathrm{~nm}$ \\
\hline 8 & $\mathrm{~nm}$ & 14.56 & 8.55 & 2.93 & 0.72 & 0.45 & 0.33 & 0.06 & 0.10 & 0.06 & 0.08 & 0.02 & 254 & 15 & $\mathrm{~nm}$ & $\mathrm{~nm}$ \\
\hline 23 & 69.01 & 15.98 & 9.06 & 2.99 & 0.83 & 0.63 & 0.42 & 0.12 & $\mathrm{~nm}$ & $\mathrm{~nm}$ & 0.14 & $\mathrm{~nm}$ & 223 & $\mathrm{~nm}$ & 0.3 & 0.9 \\
\hline 221 & $\mathrm{~nm}$ & 19.65 & 6.00 & 2.25 & 0.58 & 0.76 & 0.72 & 0.12 & 0.98 & 0.11 & 0.05 & 0.02 & 290 & 105 & $\mathrm{~nm}$ & $\mathrm{~nm}$ \\
\hline 123 & $\mathrm{~nm}$ & 19.11 & 6.08 & 2.49 & 0.5 & 0.98 & 1.36 & 0.33 & 1.71 & 0.05 & 0.05 & 0.01 & 600 & 91 & $\mathrm{~nm}$ & $\mathrm{~nm}$ \\
\hline 43 & 64.5 & 19.1 & 6.22 & 2.88 & 0.41 & 1.23 & 2.28 & 0.49 & 2.02 & $7 \mathrm{ppm}$ & 0.11 & $63 \mathrm{ppm}$ & 654 & 79 & $\mathrm{~nm}$ & $\mathrm{~nm}$ \\
\hline 14 & 66.38 & 18.54 & 5.99 & 2.47 & 0.57 & 0.92 & 1.28 & 0.33 & 1.9 & $\mathrm{~nm}$ & $\mathrm{~nm}$ & $\mathrm{~nm}$ & $\mathrm{~nm}$ & $\mathrm{~nm}$ & $\mathrm{~nm}$ & $\mathrm{~nm}$ \\
\hline 1 & 64.77 & 18.74 & 5.24 & 3.18 & 0.44 & 1.29 & 2.30 & 0.68 & 2.66 & $\mathrm{~nm}$ & $\mathrm{~nm}$ & $\mathrm{~nm}$ & $\mathrm{~nm}$ & $\mathrm{~nm}$ & $\mathrm{~nm}$ & $\mathrm{~nm}$ \\
\hline 9 & $\mathrm{~nm}$ & 18.79 & 5.74 & 2.26 & 0.49 & 0.93 & 1.14 & 0.23 & 1.39 & 0.01 & 0.05 & 0.01 & 249 & 71 & $\mathrm{~nm}$ & $\mathrm{~nm}$ \\
\hline 8 & $\mathrm{~nm}$ & 18.1 & 5.78 & 2.05 & 0.64 & 0.74 & 0.70 & 0.12 & 0.83 & 0.08 & 0.06 & 0.02 & 263 & 99 & $\mathrm{~nm}$ & $\mathrm{~nm}$ \\
\hline 16 & 63.06 & 16.54 & 6.96 & 2.14 & 1.73 & 1.84 & 1.44 & 0.19 & 0.79 & 0.34 & 0.77 & 0.49 & 600 & 16720 & 0.24 & 0.9 \\
\hline 6 & 63.44 & 17.94 & 6.73 & 2.26 & 1.46 & 1.96 & 1.26 & 0.18 & 0.73 & 0.05 & 0.83 & 0.04 & 312 & 13084 & 0.27 & 1.3 \\
\hline 5 & 64.04 & 15.54 & 6.88 & 2.04 & 1.88 & 2.24 & 1.09 & 0.10 & 0.88 & $\mathrm{~nm}$ & 1.00 & 0.10 & $\mathrm{~nm}$ & 18000 & 0.34 & 1.0 \\
\hline 5 & 64.66 & 17.26 & 6.75 & 2.32 & 1.64 & 1.76 & 1.55 & 0.20 & 1.07 & $518 \mathrm{ppm}$ & 1.06 & 0.13 & 420 & 15091 & $\mathrm{~nm}$ & $\mathrm{~nm}$ \\
\hline 12 & 62.12 & 17.10 & 6.63 & 2.62 & 1.50 & 1.85 & 1.27 & 0.18 & 0.80 & 0.29 & 0.65 & 0.29 & 100 & 16400 & 0.28 & 1.0 \\
\hline 19 & 62.69 & 16.64 & 6.47 & 2.42 & 1.70 & 2.20 & 1.34 & 0.18 & 0.86 & 0.14 & 0.73 & 0.06 & 200 & 18080 & 0.27 & 0.9 \\
\hline
\end{tabular}

Freestone, I. C., 1994, Appendix: chemical analysis of 'raw' glass fragments, in Excavations at Carthage, vol. II, 1. The Circular Harbour, north side. The site and finds other than pottery (ed. H. R. Hurst), 290, British Academy Monographs in Archaeology, no. 4, Oxford University Press, Oxford.

Freestone, I. C., Gorin-Rosen, Y., and Hughes, M. J., 2000, Primary glass from Israel and the production of glass in the late antiquity and the early Islamic period, in La route du verre: ateliers primaires et secondaires du second millénaire av. J.-C. au Moyen Âge (ed. M.-D. Nenna), 65-84, Travaux de la Maison de l'Orient Méditerranéen—Jean Pouilloux, no. 33, Lyon.

Freestone, I. C., Ponting, M., and Hughes, M. J., 2002, Origins of Byzantine glass from Maroni Petrera, Cyprus, Archaeometry, 44, 257-72.

Freestone, I. C., Wolf, S., and Thirlwall, M., 2005, The production of HIMT glass: elemental and isotopic evidence, in Annales du $16^{e}$ Congrès de l'Association Internationale pour l'Histoire du Verre, London, 7-13 September 2003, AIHV, Nottingham.

Gallo, F., Silvestri, A., and Molin, G., 2013, Glass from the archaeological museum of Adria (north-east Italy): new insights into early Roman production technologies, Journal of Archaeological Science, 40, 2589-605.

Ganio, M., Boyen, S., Brems, D., Scott, R., Foy, D., Latruwe, K., Molin, G., Silvestri, A., Vanhaecke, F., and Degryse, P., 2012, Trade routes across the Mediterranean: a $\mathrm{Sr} / \mathrm{Nd}$ isotopic investigation on Roman colourless glass, Glass Technology: European Journal of Glass Science and Technology Part A, 53(5), 217-24.

Gliozzo, E., Barbone, A. S., and D'Acapito, F., 2013, Waste glass, vessels and window-panes from Thamusida (Morocco): grouping natron-based blue-green and colourless Roman glasses, Archaeometry, 55, 609-39.

Hall, R., 1984, The Viking dig, Bodley Head, London.

Henderson, J., 1996, Scientific analysis of selected Fishbourne vessel glass and its archaeological interpretation, in Chichester excavations, 189-92, Chichester Civic Society Excavations Committee, Chichester.

Jackson, C. M., 1992, Compositional analysis of Roman and early post-Roman glass and glassworking waste from selected British sites, Unpublished Ph.D. thesis, University of Bradford.

Jackson, C. M., 1994, Appendix 1: compositional data from the Romano-British glassmelting debris from Mancetter and Leicester, in Exploratory multivariate analysis in archaeology (M. J. Baxter), Edinburgh University Press, Edinburgh.

Jackson, C. M., 2005, Making colourless glass in the Roman period, Archaeometry, 47, 763-80.

Jackson, C. M., and Cottam, S., in preparation, Compositional and typological observations concerning the production of emerald green glass vessels in the 1st century A.D. 
Jackson, C. M., and Price, J., 2012, Analyses of late Roman glass from the Commandant's House of the fort at South Shields, Tyne and Wear, UK, Annales du $18^{e}$ Congrès de l'Association Internationale pour l'Histoire du Verre (Thessaloniki 2009), 181-8, AIHV, Corning, NY.

Jackson, C. M., Cool, H. E. M., and Wager, E. C. W., 1998, The manufacture of glass in Roman York, Journal of Glass Studies, 40, 55-61.

Jackson, C. M., Price, J., and Lemke, C., 2009, Glass production in the 1st century A.D. Insights into glass technology, in Annales du $17^{e}$ Congrès de l'Association Internationale pour l'Histoire du Verre (Antwerp 2006), 150-156.

Jackson, C. M., Hunter, J. R., Warren, S. E., and Cool, H. E. M., 1991, The analysis of blue-green glass and glassy waste from two Romano-British glass working sites, in Archaeometry '90: international symposium on archaeometry, Heidelberg, Germany 2-6 April 1990 (eds. E. Pernicka and G. A. Wagner), 295-305, Birkhäuser Verlag, Basel.

Jackson C. M., Wager, E. C., Joyner, L., Day, P. M., Booth, C. A., and Kilikoglou, V., 2003, Small-scale glass making at Coppergate, York: analytical evidence for the nature of production, Archaeometry, 45, 435-56.

Mainman, A., 1990, Anglo-Scandinavian pottery from York, The Archaeology of York 16/5, Council for British Archaeology, York.

Meek, A., 2013, Gold glass in Late Antiquity: scientific analysis of the British Museum collection, in New light on old glass: recent research on Byzantine glass and mosaics (eds. C. Entwistle and L. James), 121-30, British Museum Research Publication 179, British Museum, London.

Mirti, P., Casoli, A., and Appolonia, L., 1993, Scientific analysis of Roman glass from Augusta Praetoria, Archaeometry, 35, 225-40.

Paynter, S., 2006, Analyses of colourless Roman glass from Binchester, County Durham, Journal of Archaeological Science, 33, 1037-57.

Paynter, S., 2008, Experiments in the reconstruction of Roman wood-fired glassworking furnaces: waste products and their formation processes, Glass Studies, 50, 271-90.

Paynter, S., 2010, Analyses of colourless Roman glass, in The beautiful rooms are empty. Excavations at Binchester Roman Fort, County Durham 1976-1981 and 1986-1991. Part 2 (I. Ferris), 333-8, Durham County Council, Durham.

Paynter, S., and Jackson, C. M., forthcoming, The supply, use and recycling of colourless glass in Roman Britain.

Price, J., 2005, Glass-working and glassworkers in cities and towns, in Roman working lives and urban living (eds. A. MacMahon and J. Price), 167-90, Oxbow, Oxford.

Price, J., and Cottam, S., 1998, Romano-British glass vessels: a handbook, Practical Handbooks in Archaeology, no. 14, Council for British Archaeology, York.

Sayre, E. V., 1963, The intentional use of antimony and manganese in ancient glasses, in Advances in glass technology: history papers and discussions of the technical papers (eds. F. R. Matson and G. E. Rindone), 263-82, Plenum Press, New York.

Sayre, E. V., 1964, Some ancient glass specimens with compositions of particular archaeological significance, 1-25, Brookhaven National Laboratory, Upton, NY.

Schibille, N., Degryse, P., O’Hea, M., Izmer, A., Vanhaecke, F., and Mckenzie, J., 2012, Late Roman glass from the 'Great Temple' at Petra and Khirbet Et-Tannur, Jordan-technology and provenance, Archaeometry, 54, 997-1022.

Silvestri, A., 2008, The coloured glass of the Iulia Felix, Journal of Archaeological Science, 35, 1489-501.

Silvestri, A., Molin, G., and Salviulo, G., 2008, The colourless glass of Iulia Felix, Journal of Archaeological Science, 35, 331-41.

Tal, O., Jackson-Tal, R. E., and Freestone, I. C., 2004, New evidence of the production of raw glass at late Byzantine Apollonia-Arsuf, Israel, Journal of Glass Studies, 46, 51-66.

Thirion-Merle, V., 2005, Les verres de Beyrouth et les verres du Haut Empire dans le monde Occidental et Oriental: étude archéométrique, Journal of Glass Studies, 47, 37-53.

Turner, W. E. S., and Rooksby, H. P., 1959, A study of the opalising agents in ancient glasses throughout three thousand four hundred years, Glastechnische Berichte, 8, 17-28.

Velde, B., 1990, Alumina and calcium oxide content of glass found in Western and Northern Europe, first to ninth centuries, Oxford Journal of Archaeology, 9, 105-17.

Vichy, M., Picon, M., and Thirion-Merle, V., 2003, Le manganèse comme impureté, décolorant ou colorant des verres au natron, Bulletin de l'AFAV, 15-17. 